\title{
Розин B.M.
}

\section{Культуры детства и старости: становление индивидуальной жизни и её завершение}

\begin{abstract}
Аннотация: В статье формулируются проблемы, заставляющие по-новому осмыслять детство и старость как две рамки (становление и завершение), замыкающие индивидуальную жизнь человека. Рассматриваются филогенетические параллели развитию ребенка в детстве. Водится представление о культурах человека, которые характеризуются особенностями жизнедеятельности и видения (сознания), а также характером форм социализации. Детство - это не только самостоятельная культура жизни, но и начало трудного перехода от одной жизни к другой (от «прамы» кличности). В детстве два основных способа освоения мира: игра и формирование первых социально значимых практик. Ребенок осваивает взрослый мир посредством игры, «мыслит» схемами. Смысл кризиса детства, о котором сегодня много говорят, - это кризис нашей, взрослой жизни. Как культура жизни старость складывается при условии, что общество признает своеобразие жизни пожильх людей и создает специальные условия для такой жизни. Другое условие - усилия и работа самих пожилых людей и стариков: выстраивание своего рода концепции старости и ее реализация. Третье осмысление старости в культуре (литература, музыка, наука и прочее), создание «семиотики старости». Рассматриваются различные концепции старости и такой важный их компонент как конституирование в этой культуре смысла жизни. Основные методы исследования: сравнительный анализ, методологическая проблематизация, культурно-историческая реконструкция, анализ кейсов. Общая методология - философское осмысление, опирающееся на гуманитарный и культурологический подходы. На основе проведенного исследования удалось ввести понятия культуры детства и старости, показать при каких условия они формируются, в чем особенности и сущность каждой культуры, какие проблемы стоят в их отношении, какие основные направления решения этих проблем. $B$ целом автор предлагает новую философскую концепцию детства и старости.
\end{abstract}

Review: The author of the present research article raises the issues that make us take another look at childhood and old age as the frames (development and completion) of human's individual life. The author views phylogenic parallels to the child development and introduces the concept of human cultures, the latter being described in terms of peculiarities of life activities and views (consciousness) as well as the nature of socialization processes. Childhood is not only an independent culture of life but also the beginning of a difficult transition from one life to another (from the 'pram' to personality). Childhood provides the two methods of the world development - play and first social contacts with significant others. A child understands the adult world through play and thinks according to particular patterns. The meaning of a so-called childhood crisis so many people are talking about now is in the crisis of our adult life. Old age develops as a culture of life only if the society admits singularity of life of elderly people and creates special conditions for their life. The other condition is the efforts and work put forth by elderly people and old people towards developing their own concept of old age and putting that concept into life. The third condition for developing the concept of old age in culture (literature, music, science and etc.) is the creation of so called 'semiotics of old age'. The author views different concepts of old age and analyzes a very important element of these concepts, institutionalization of the meaning of life in the culture of old age. The main research methods used by the author included comparative analysis, methodological problematisation, cultural and historical reenactment and case analysis. General methodology included the philosophical interpretation based on humanitarian and cultural approaches. Based on the results of the analysis carried out, the author offered the definition of the term 'culture of childhood and culture of old age' and described the conditions of their formation, peculiarities and essence of each culture, issues related to these cultures and the main solutions of these issues. Generally speaking, the author offers a new philosophical concept of childhood and old age.

Ключевъе слова: культура, детство, старость, реальность, личность, прамы, общество, социум, деятельность, становление.

Keywords: culture, childhood, old age, reality, personality, prams, society, activity, development. 


\section{Проблематизация детства}

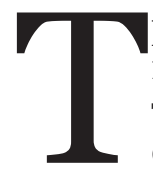
радиционная постановка проблемы, направленная на осмысление некоторого явления звучит так: какова его сущность? Но сущность задается часто через противоречие в знаниях, характеризующих данное явление. Вот и по поводу детства можно сформулировать ряд противоречий. С одной стороны, детство характеризуется в рамках традиционного психологического представления о развитии психики и поэтому наделяется константными свойствами, заставляющими думать, что детство как сущность всегда было и в каком-то смысле неизменно. С другой стороны, современные культурноисторические и кросс-культурные исследования детства убедительно демонстрируют, что детство сложилось не раньше XII-XIII вв. и существенно различается в разных культурах.

Наиболее последовательно первая трактовка детства проведена в книге «Психология детства» (под редакцией А.А.Реана, 2003). «Анализ этих положений и материалов, - пишут авторы, позволил В. П. Зинченко (см.: В. П. Зинченко, Е. Б. Моргунов, 1994) вычленить некоторые важнейшие принципы, характеризующие процессы психического развития ребенка, которые уже сейчас являются руководящими как при разработке основ и проектировании системы обучения, воспитания детей, так и при организации исследования детства. Среди них:

1) творческий характер развития, проявляющийся в порождении ребенком знаков, символов, когда он уже с младенчества выступает как субъект культуры;

2) ведущая роль социокультурного контекста развития, по-разному проявляющаяся в разных периодах, влияя, например, в школьном возрасте на процессы формирования образа мира, стиля поведения и деятельности;

3) особая значимость сенситивных периодов развития (разных для разных возрастов), т. е. периодов, наиболее чувствительных к осознанию, усвоению и реализации норм, форм, условий человеческой жизнедеятельности (языка, способов общения и т. д.);

4) совместная деятельность взрослых и детей как движущая сила развития ребенка, передача детям взросльми достижений исторического развития человека;

5) наличие ведущей деятельности в каждом возрастном периоде и законы ее смены как основа преемственности периодов психического развития ребенка;
6) определение зоны ближайшего развития растущего человека;

7) амплификация (расширение) детского развития как условие свободного поиска и нахождения ребенком себя в материале, той или иной форме деятельности и общения;

8) непреходящая ценность для формирования полноценной личности всех этапов детского развития;...

11) интериоризация и экстериоризация как механизмы развития;

12) неравномерность (гетерохронность) развития, учитывать которую чрезвычайно важно, представляя при этом не только его уровни и компоненты, но и весь «фронт» развития» ${ }^{1}$ (курсив наш. - B.P.)

C точки зрения такой теоретической трактовки детства, фиксирующей законы и механизмы психического развития (на чем особенно настаивал П.Я.Гальперин, идя здесь вслед за Л.С.Выготским) детство выглядит как константное, практически вечное образование, которое лишь по-разному осознается в истории, но не меняется в своей сущности. Даже когда психологи хотят учесть культурно-исторические исследования детства, они не могут выйти за границы данной трактовки

«Детство, - читаем в историческом обзоре изучения этого феномена в психолого-педагогической науке, - период, продолжающийся от новорожденности до полной социальной и, следовательно, психологической зрелости; это период становления ребенка полноценным членом человеческого общества. При этом продолжительность детства в первобытном обществе не равна продолжительности детства в эпоху средневековья или в наши дни. Этапы детства человека - продукт истории, и они столь же подвержены изменению, как и тысячи лет назад. Поэтому нельзя изучать детство ребенка и законы его становления вне развития человеческого общества и законов, определяющих его развитие<...>

Известно, что механизмы социализации и символические представления о детстве в Средневековье были иными, чем в Новое время и наше. Средневековой мысли было известно понятие “возрастов" или эпох жизни, но за ними не стояла идея развития личности. В живописи раннего Средневековья ребенок обычно изображался как уменьшенная копия взрослого. Вплоть до XVII в. не было специ-

\footnotetext{
${ }^{1}$ Психология детства. Учебник. М., 2003. Часть первая «Обзор основных теорий», параграф 13 «Особенности процесса развития детства».
} 
фически детских костюмов: как только ребенок расставался с пеленками, его начинали одевать по соответствующей сословию моде». Современный ребенок, неся в себе историческую память человеческого детства, остается тем не менее человеком своей эпохи. В какой мере? Почему в его поведении, играх, языке присутствуют одновременно отголоски прежних эпох, утраченных форм и представлений? ребенок живет в условиях диалога эпох, диалога культур »².

Как мы видим, авторы сидят на двух стульях: признавая историко-культурную обусловленность феномена детства, они, тем не менее, мыслят детство в понятиях психического развития и разных форм его осознания 3 .

Вторая трактовка детства (правда, не всегда последовательно) проведена в книгах М.Мид и Ф. Арьеса, а также книгах И. Кона 4 .

В.В. Абраменкова тоже выделяет «парадоксы и противоречия в изучении ребенка», которые, с нашей точки зрения, относятся не столько к противоречиям познания детства, сколько к противоречиям самого данного феномена в современной культуре:

«Демократизация детской жизни, юридические свободы, зафиксированные в международных, государственных и других документах, - и ограничение (особенно в больших городах) пространства детской жизнедеятельности, фактическое лишение неотъемлемого права ребенка на игру, прежде всего, традиционную для всех культур - игру со сверстниками.

Ценность детей и брака, формирование родительских установок и особой эмоциональной связи с ребенком, жизнь семьи «ради детей» - и резкое снижение рождаемости, осознанное безбрачие: «ценность детей становится самостоятельным фактором, мотивирующим ограничение рождаемости,- таков парадокс нашего времени».

\footnotetext{
${ }^{2}$ Детство как предмет научного исследования 1. Исторический обзор изучения детства в психолого-педагогической науке. http://vkjournal.ru/ doc/105031.

3 Здесь можно поставить такой принципиальный вопрос: а меняется ли феномен в ходе его осознания? Явления первой природы, конечно, не меняются, а вот «явления духа» или социокультурные, как известно, включают рефлексию в свою сущность.

${ }^{4}$ Арьес Ф. Ребенок и семейная жизнь при Старом порядке. Екатеринбург: Изд-во Урал, ун-та, 1999; Кон И. С. Открытие «Я». - М., 1978; Кон И. С. Ребенок и общество. - М., 1988; Мид М. Культура и мир детства. - М., 1988.
}

Повышение в последнее десятилетие уровня жизни ребенка (рост потребления товаров и услуг, повышение жизненного комфорта, механизация быта, количество и качество детской индустрии развлечений - книг, фильмов, игрушек для детей и пр.) - и снижение качества жизни (субъективной удовлетворенности ребенка условиями его бытия, его психоэмоциональное благополучие, оптимизм).

В России последние обстоятельства выражены особенно резко - в виде тревоги, апатии, пессимизма, прежде всего как проявления нравственно-духовного неблагополучия.

Инфантицид как детоотвержение, детоубийство в формах отказа от здоровых детей, миллионов абортов, социального сиротства, детской беспризорности и растущая адопция (усыновление/удочерение) чужих детей, включая детей-инвалидов» 5 .

Сюда же можно добавить и работы Д. Фельдшейна. Например, в докладе «Глубинные изменения современного детства и обусловленная ими актуализация психолого-педагогических проблем развития образования», он пишет: «И все это происходит на фоне того, что популяция самого Детства в нашей стране стремительно сокращается - начиная с 90-х годов мы потеряли 14 миллионов (вместо 40 у нас сегодня 26 млн. детей, в том числе 1,5 млн. детей, находящихся, по официальным данным, в зоне риска). При этом рухнули многие образующие структуры Детства, изменились отношения между детьми, в том числе усилились их «горизонтальные» связи, что особенно выпукло проявляется в подростковый период. Отмечается интенсивная примитивизация сознания детей, рост цинизма, грубости, жестокости, агрессивности. А за этими внешними проявлениями кроются внутренние глубинные переживания ребенка - неуверенности, одиночества, страха, и в то же время инфантилизм, эгоизм, духовная опустошенность, то есть те современные приобретения Детства, которые являются тяжелой потерей для него...

В числе многих факторов, определяющих глубинные изменения растущих людей, выступает, во-первых, маркетизация, этика рынка, усиливающая ориентацию детей на потребление, а также адопция, отрывающая ребенка от культурных традиций общества и его истории; во-вторых, маргинализация,

\footnotetext{
${ }^{5}$ Абраменкова В.В. Социальная психология детства в контексте развития отношений ребенка в мире // Вопросы психологии. 2002. N 1. С. 3.
} 
то есть неравный доступ к образовательным ресурсам в мегаполисе и провинции, рост девиаций, стремление родителей ограничивать активность и самостоятельность ребенка. Под действием этих и других факторов мы получаем такие феномены, как медикализация, выражающаяся в том, что детям ставят диагнозы, которые ранее ставили взрослым, при использовании антидепрессантов для агрессивных детей; повышенный уровень тревожности и страхов ребят, а в ряде случаев - повышенную агрессивность под действием фактора милитаризации и развития компьютерных игр, снижающих контроль детей за собственным поведением и формирующих тревожную зависимость» ${ }^{6}$.

Эта печальная констатация позволяет сформулировать еще одну проблему, выступающую для педагогики детства как настоящий вызов. А именно, каким образом и в каком направлении нужно воспитывать детей, учитывая изменения условий жизни, о которых пишут Абраменкова и Фельдштейн и другие исследователи. К числу этих изменений, с философской точки зрения, относятся также кризис реальности и неопределенность будущего. В условиях неопределенности и перехода (а мы живем во время перехода, когда по выражению С.С Неретиной «одна реальность уже ушла, а новая еще не опознана ${ }^{7}$ и цели образования выглядят неопределенными.

И в самом деле с будущим в настоящее время что-то неблагополучно. Насколько ясно воспринималось будущее во второй половине прошлого века, настолько неопределенно и бледно сегодня. Социологические исследования показывают, что россияне планируют свое будущее не больше чем на полгода, от силы год. В чем же сущность нашего понимания будущего? Не в том ли, что в Новое время будущее было тесно связано, с одной стороны, с прогрессом, понимаемым естественнонаучно, с другой - с креативной деятельностью человека (хотя прогресс обусловлен естественными причинами, но он существенно определяется и творчеством человека). При этом считается, что действие природы и творчество человека распространяются и на него самого. Успехи естествознания и инженерии (в том числе социальной - тоталитарные институты, идеология, СМИ, пиар) обусловили во второй половине XIX, первой XX столетия убежде-

\footnotetext{
${ }^{6}$ http://rudocs.exdat.com/docs/index-370609.html

7 Неретина С.C. Точки на зрении. Санкт-Петербург, 2005. С. 258, 273.
}

ние, что будущее понятно и достижимо. Человеку показалось, что оно уже почти поймало эту жар-птицу, что, оседлав будущее, человечество легко въедет в земной рай.

Но жар-птица будущего легко вырвалась из рук, вильнула хвостом и куда-то унеслась. Спрашивается, почему? Не потому ли, что, начиная со второй половины XX столетия, были осознаны границы естествознания и инженерии и лавинообразно стали нарастать негативные последствия научно-технического прогресса. Не потому ли, что проекты все больше расходились с их реализацией (замышлялось и проектировалось одно, а получалось другое, причем социальная и индивидуальная реальности так трансформировались, что человек уже не мог с этим примириться).

Современный человек научился так интерпретировать события и затем вменять полученные интерпретации себе и другим, что реальность стала неопределенной и мерцающей, то она выглядит так, то эдак. Очень вероятно, что и дальше мы будем наблюдать победное шествие техники и технологии и связанную с ними глобализацию мира. Но возможно, этот тренд сменится другим. Некоторые вслед за Гегелем думают, что разум и согласие на нашей планете возрастают. Другие, напротив, по Платону пророчат, что нас ожидает борьба всех против всех. Сторонники техногенной цивилизации считают, что человек сможет организовать под себя земную природу. Но «зеленые» и антиглобалисты думают иначе - природа накажет зазнавшегося человека ураганами, цунами, эпидемиями. Как верно заметил Г.Померанц, хотя «Новое время кончилось и начался поворот неизвестно куда, эпоха дрейфа, потери и обновления ориентиров», тем не менее, «все попытки увековечить современное состояние мира, нынешний стиль восприятия жизни необоснованны»; «история культуры - это история обуздания новых стихий» ${ }^{8}$. Вопрос, удастся ли обуздать на этот раз?

В ситуации неопределенности и сложности реальности ясно и непротиворечиво помыслить будущее становится невозможным и, следовательно, затруднительно ответить и на вопросы типа: что нас ожидает, куда идет развитие человека, какие требования к нему предъявляет меняющееся время и др. Конечно в педагогической литературе предлагаются и обсуждаются много разных стратегий вос-

8 Померанц Г.С. Постмодернизм // Новая философская энциклопедия. В 4 т. М, 2001. Т. 3. С. 298. 
питания, но ни одна из них в настоящее время не основывается на ясном понимании будущего и реальности.

Есть еще одна проблема - границ и периодизации детства. Интуитивно наши представления о детстве заканчивается на периоде начальной школы. Однако некоторые психологи и педагоги продлевают детство, утверждая, что в него входят подростковый и юношеский этапы формирования человека. Вспомним: «Детство - период, продолжающийся от новорожденности до полной социальной и, следовательно, психологической зрелости; это период становления ребенка полноценным членом человеческого общества». По поводу подобных границ М. Кле отмечает следующее.

«Основная проблема в установлении продолжительности отрочества в ходе индивидуального развития состоит в определении его конца. Отрочество заканчивается с вхождением человека в мир взрослых, однако, по крайней мере, в нашем обществе достижение взрослого статуса не имеет точных, общепринятых критериев. Переход от отрочества к взрослости представляет скорее, усложняющийся процесс, за которым стоит важный период индивидуального развития. Можно выделить определенное число событий, которыми отмечен этот переход: окончание учебы, включение в рынок труда, уход из родительского дома, нахождение партнера и создание собственной семьи. Однако как мы уже отмечали порядок этих событий и время их протекания меняются в ходе истории. Достижение взрослого статуса также меняется в зависимости от эпохи и культуры; в нашем обществе оно не институализировано и определяется по смутным, изменчивым критериям... Небольшую ясность вносит Хоррокс, когда утверждает: “отрочество кончается, когда индивид достигает социальной и эмоциональной зрелости и получает опыт, способность и желание принять на себя роль взрослого, выражающуюся в широком веере поступков - так, как она задана культурой, в которой живет”. Эти дефиниции отражают, скорее, замешательство исследователей, когда речь заходит об исчерпывающем определении окончания отрочества; этот период развития между детством и взрослостью, имеющий биологическое начало и определяемый культурой конец»9.

\footnotetext{
${ }^{9}$ Кле М. Психология подростка // Фролов Ю.И. Психология подростка.М., 1997. С. 121. http:// www.gumer.info/bibliotek_Buks/Psihol/Article/ kle_psih.php
}

Но другие исследователи не включают в детство отрочество и разбивают его на иные этапы. Например, Ж. Годфруа пишет, что «традиционно принято разделять жизненный цикл на четыре больших периода: пренатальный (внутриутробный) период, детство, отрочество и зрелость (взрослое состояние). В свою очередь каждый из этих этапов состоит из нескольких стадий, имеющих ряд характерных особенностей» ${ }^{10}$.

Короче, никаких общепринятых критериев этапизации и проведения границ детства не существует, хотя эмпирические различения, конечно же, вводятся каждым исследователем, и часто они выглядят достаточно убедительными. Можно еще вспомнить мнение В.В. Зеньковского, который пишет, что «гораздо сложнее и запутаннее представляется нам развитие юного существа, если обратиться к чисто психической стороне в нем. Отсутствие единства в развитии отдельных психических функций, отдельных сторон в психической жизни не позволяет положить в основу деления детства на периоды развитие какой-либо одной (признаваемой за основную) функции. Здесь-то и лежат корни самых острых разногласий между психологами - именно по вопросу о том, каким процессам должно отвести основное значение в психическом созревании ребенка» ${ }^{11}$.

Целый ряд проблем касаются объяснения генезиса детства. Например, вот родился ребенок, спрашивается, кто это - человек или животное? Вопрос может показаться странным: конечно, человек. Но как тогда быть с феноменом Маугли: если родившийся ребенок - человек, то каким образом, попав к животным, он становится животным? Если родившийся ребенок - еще только животное, то каким образом он становится человеком? И почему, хотя ребенок еще не понимает ни одного слова, мы разговариваем с ним как с взрослым?

Не менее сложная генетическая проблема: каким образом складываются способности ребенка (память, воображение, мышление и пр.) и все ли именно в детстве? Чтобы понять, какие здесь трудности, возымем для примера способность к мышлению и последнюю большую работу Л.С. Выгодского «Мышление и речь». С одной стороны, истоки мышления Выготский

${ }^{10}$ Годфруа Ж. Что такое психология. В 2-х т. Т. 2. M., 1992.

${ }^{11}$ Зеньковский В.В. Психология детства. Ред. Golden-Ship.ru 2012. (Текст публикуется по изданию: Зеньковский В.В., проф. Психология детства. Лейпциг: Изд-во «Сотрудник», 1924). С. 58. 
видит чуть ли не в биологической природе человека. «Не является для марксизма, - пишет Выготский, - сколь-нибудь новым то положение, что в животном мире заложены корни человеческого интеллекта... во всяком случае, нет основания отрицать наличие генетических корней мышления и речи в животном царстве, и эти корни, как показывают все данные, различны для мышления и речи» ${ }^{12}$.

С другой стороны, Выготский предлагает изучать мышление фактически как речь, ставя в центр рассмотрения слово и его значение, а также разные формы речи - эгоцентрическую, внутреннюю, внешнюю. Тогда получается, что мышление совпадает с речью. Чтобы убедить читателя, Выготский цитирует Штерна, описывающего «величайшее открытие» ребенком около двух лет наличие у каждой вещи своего имени. «Только что описанный процесс, - говорит Штерн, - можно уже вне всяких сомнений определить как мыслительную деятельность ребенка в собственном смысле слова» ${ }^{13}$. Комментируя Штерна, Выготский заключает: «...лишь на известной, относительно высокой стадии развития мышления и речи становится возможным “величайшее открытие в жизни ребенка”. Для того чтобы “открыть” речь, надо мыслить» ${ }^{14}$ «Всякое же обобщение, всякое образование понятия есть самый специфический, самый подлинный, самый несомненный акт мысли. Следовательно, мы вправе рассматривать значение слова как феномен мышления ${ }^{15}$.

Правда, Выготский постулирует, что «значение в равной степени может рассматриваться и как явление речевое по своей природе, и как явление, относящееся к области мышления» и поэтому есть все основания рассматривать значение слова «как единство мышления и речи...» ${ }^{16}$. Но отсюда ведь не следует, что мышление совпадает с речью, и что поэтому мы можем его анализировать как речь или язык. Кроме того, сам этот постулат в свете современной гуманитарной науки (языкознания и семиотики) является достаточно сомнительным. Можно согласиться, что мышление предполагает речь, но означает ли это, что мышление формируется в речи, так сказать, появляется из неё? Почему все-таки Выгот-

\footnotetext{
T.2, M.,1982. C. 112, 113 .

${ }^{13}$ Там же. С. 93.

14 Там же. С. 105

15 Там же. С. 297.

${ }^{16}$ Там же. С. 17.
}

12 Выготский Л.С. Мышление и речь. Собр. соч. ский решил, что появление у слов значений - это уже мышление и образование понятий? Ведь он сам показывает, что детское мышление представляет собой «комплекс» и «псевдопонятие», причем комплексы существенно отличаются от мышления в понятиях, которое складывается значительно позднее ${ }^{17}$.

Нельзя сказать что Выготский не чувствовал противоречие, напротив, он пытается провести особое рассуждение, стараясь доказать возможность трансформации речевой функции в мыслительную, и так сближает комплексыпсевдопонятия с понятийным мышлением, чтобы казалось, что вот-вот одно перетечет в другое. С этой целью Выготский, например, утверждает, что эгоцентрическая речь у ребенка «очень легко становится мышлением в собственном смысле этого слова, что благодаря коммуникативной функции речи (взаимопониманию) слова становятся понятиями, а речь - мышлением, что в связи с тем, что речь ребенка развивается не свободно, не спонтанно, а под давлением организованной речи и значений взрослых, псевдопонятия сближаются с понятиями» ${ }^{18}$. Но ни одно из этих утверждений не доказывает, что речь может стать мышлением, а псевдопонятие могут развиться в понятие.

Наконец, с третьей стороны, мышление Выготский связывает с решением задач, рассуждениями, использованием системы понятий и другими достаточно сложными мыслительными действиями, предполагающими, как отмечает Выготский, произвольность и осознанность и формирующимися не раньше, чем с подросткового возраста.

Постановку проблем детства можно продолжать, но и тех, которые сформулированы,

\footnotetext{
${ }^{17}$ Выготский колеблется: то он называет комплексы мышлением, то показывает, что комплексы больше напоминают сновидения, произведения искусства - все, что угодно, только не мышление. Например, он пишет: «Если мы возьмем формы человеческого мышления, проявляющиеся в сновидении, то обнаружим там этот древний примитивный механизм комплексного мышления, наглядного слияния и передвижения образов». Обратим внимание на парадоксальное выражение - «формы человеческого мышления, проявляющиеся в сновидении», в сновидении, где, как известно, вообще не действует контроль сознания и нет никакого мышления. А страницей выше Выготский пишет, что комплекс - это не понятие, а скорее «картина», «умственный рисунок понятия», «маленькое повествование о нем», «художественное произведение». (Там же. С. 167,168 )

${ }_{18}$ Там же. С. $108,124,149$.
} 
достаточно, чтобы сделать следующий шаг в развитии представлений о детстве.

Прежде всего, в переосмыслении нуждаются представления о том, что такое развитие человека и какую роль здесь играет образование. Традиционное понимание в основном психологическое. Образование, включающее обучение и воспитание, создает условия для развития психики и личности, идущие от детства через отрочество и юношество к взрослому состоянию человека. При этом, как отмечалось, указанные состояния («детства», «отрочества и юности», «взрослого индивида») понимаются как состояния человека, рассматриваемого как единое существо ${ }^{19}$. В отличие от этого современная философия позволяет нарисовать другую картину, которую мы кратко охарактеризуем.

\section{Три «культуры жизни человека»}

Единым человек является только в биологическом плане, как культурное и, возможно духовное существо, человек - не един. Существуют несколько «культур жизни человека» (мы предлагаем ввести такое понятие как «культура жизни»): «культура детства», «культу-

19 «Основная наша ошибка в отношении детей, - пишет Зеньковский, - заключается в том, что мы считаем детскую душу решительно и во всем схожей с нашей, исходим из мысли, что в детской душе имеют место те же психические движения, что и у нас, только еще неразвитые, слабые. Детская душа, с этой точки зрения - это душа взрослых в миниатюре, это ранняя стадия в ее развитии. Различие между душой ребенка и взрослого имеет, согласно этому популярному взгляду, количественный, а не качественный характер. Отдельные психические движения у них слабы, другие едва лишь намечены, соотношение психических сил благодаря этому несколько иное, чем у нас, - но общий психический склад у нас тот же, что у детей... Но неужели слабое и недостаточное развитие некоторых психических функций создает своеобразие детства? Достаточно сравнить с нормальными детьми тех психически отсталых взрослых, у которых недоразвиты или слабо развиты какие-либо психические силы, чтобы убедиться в том, что своеобразие детства в очень малой степени создается психическим недоразвитием. Психический инфантилизм у взрослых сближает их с детьми, но совсем не превращает их в настоящих детей, у которых слабое развитие некоторых психических функций является не причиной, а следствием присущего им своеобразия...Каков же смысл детства, какова его функция в созревании человека? Очевидно, продолжительность детства может быть понята лишь в том случае, если детство, как таковое, имеет какую-то особую функцию» (цит, соч. С. 24-25). ра отрочества и юности», несколько «культур взрослого человека». Каждая культура жизни человека характеризуется особенностями жизнедеятельности и видения (сознания), а также характером социализации; в первых двух культурах важное место занимает образование.

Детство - это не только самостоятельная культура жизни, но и начало трудного перехода от одной жизни к другой (от «прамы» к личности $\left.{ }^{20}\right)$. В детстве два основных способа освоения мира: игра и становление первых социально значимых практик (умения есть, пить, говорить, одеваться, общаться с взрослыми, помогать им и т.п.). В «Я» ребенка имплицитно входят и его родители, которые могут быть рассмотрены как его «социальное тело» ${ }^{21}$. Смысл кризиса детства, о котором сегодня много говорят, - это прежде всего кризис нашей, взрослой жизни. Современный человек создал жизнь, которая разрушает и его самого и детей ${ }^{22}$. Родители не живут вместе со своими детьми, передают их на воспитание другим. Сегодня чуть ли не главный воспитатель - среда, гедонистически ориентированная культура. Мы, взрослые, сами не знаем, как жить. Отсюда, детство - это «переход в переходы», в неопределенность.

Можно различить две разные зоны детства. В первой («безопасной») мы по-прежнему ведем ребенка и являемся его способностью. Во второй («опасной») родители учатся жить вместе со своими детьми. Выясняют для себя и детей, что можно, а что нельзя. Ответственные родители вынуждены кардинально пересматривать свою жизнь. Их направляют - любовь к детям, разум, осмысление последствий наших поступков и поступков детей.

Отрочество и юность - не менее самостоятельная культура жизни. Её центральный процесс - становление личности (не развитие личности, а только постепенное её складывание через пробы и ошибки). Под-

\footnotetext{
20 «Прамы» - термин Л.С. Выготского, призванный подчеркнуть единство ребенка со своими родителями. ${ }^{21}$ В чем культурный смысл детской игры? Это доступный ребенку способ освоения взрослого мира и первая репетиция свободы личности. Родители для своих детей являются настоящей способностъю («социальным телом»), как только дети сталкиваются с проблемами, которые не могут решить, то тут же прибегают к помощи родителей. Мы со своими детьми - одно целое. Я не только отец для своего ребенка и субъект, с которым он общается, но и его органическая способность, позволяющая решать недетские задачи.

${ }^{22}$ Соблазн желаний, соблазн техникой.
} 
ростковая культура начинает формироваться, когда родители (общество) посылают ребенка в школу, где от него требуют действовать самостоятельно ${ }^{23}$. В значительной степени и школа и родители блокируют теперь для отрока возможность решать свои проблемы в сфере игры и фантазии (сказки). Напротив, объем обучения постоянно возрастает, а требование действовать рационально становится основным. Существенно изменяются и социальные отношения: вместо родительской опеки и поддержки складываются двусторонние властные (с педагогами и значимыми взрослыми) и равноправные (с друзьями) отношения.

Под давлением взрослых и школы распадается прамы, отрок начинает переходить к самостоятельному поведению, учится управлять сам собой (планирует свои занятия, позиционируется по отношению к другим, центрирует мир на своем $Я$, разделяет внутреннее и внешнее и прочие метаморфозы, достаточно хорошо описанные в художественной и психологической литературе). Отрочество неотделимо от школы и образования, в связи с чем на первый план выдвигается не игра, а рациональные типы поведения (учеба, рассуждения, первые анализы последствий своих поступков и пр.).

Хотя объективное наблюдение показывает, что образ себя (своего Я) складывается при отождествлении себя с привлекательным (значимым) образом «Другого», субъективно подросток считает, что Я - это он сам. Целый ряд признаков своего «Я» у подростка и юноши обусловлены влиянием школьного обучения и образования, это объясняет, почему образ себя отчасти представляет собой рациональное построение. При этом стоит отметить, что процесс освоения образа себя включает план игры и фантазии. Подросток (юноша, девушка) как бы играет во взрослого, но осознаются им эти игры вполне серьезно, как его настоящая жизнь.

У подростка самостоятельное поведение, опирающее на образ себя, часто, входит в противоречие с его реальным поведением и отношениями, которые сформировались в этот период. Возникшие при этом проблемы вызывают как негативные переживания,

\footnotetext{
23 «При том биологическом понимании детства, которое установилось в нашей науке после Гроca, - пишет Зеньковский, - детство (в широком смысле слова) обнимает все те годы, когда человек еще не подготовлен к самостоятельной жизни, к самостоятельной борьбе за существование» (Зеньковский В. Цит. соч. С.57).
}

так и особые формы поведения - упрямство, конфликты, отрицание взрослых, самоуничижение, стремление любой целой доказать свою значимость и т.п. ${ }^{24}$ Но рано или поздно эти проблемы приводят к уточнению или смене образа себя, в результате чего начинается новый цикл развития подростка. Через такую неоднократную смену образа себя подросток нащупывает более реалистическую позицию в мире взрослых и осваивает более реалистические формы поведения ${ }^{25}$.

24 «Впервые, - отмечает Зеньковский, - в зреющей душе появляется настоящий интерес к своей собственной личности, подросток чрезвычайно занят самим собой, своими замыслами, своей внешностью, своими переживаниями, погружается в свои мечты. Именно к этому времени наблюдается чрезвычайное развитие фантастики, сознательного ухода из реальности. Отрок идет еще дальше, чем это наблюдается во втором детстве, в противоположении внутреннего и внешнего мира, - но в новом периоде его внимание всецело обращено к внутреннему миру. Крайний и ясно сознаваемый субъективизм кладет печать на всю активность подростка, которая нередко бывает отмечена некоторым вкусом к авантюре. Несбыточность мечтаний, нереальность планов, неблагоразумие избираемого пути вовсе не смущают подростка, а часто даже психически поднимают в нем вкус к движению в данном направлении. Подросток как бы обретает в самом себе, в своих порывах и устремлениях, единственное руководящее начало, всякие авторитеты теряют в это время свое влияние, подросток начинает верить только самому себе, своему личному опыту. Моральное развитие обыкновенно принимает характер критического отношения ко всему тому, что доныне освещало путь жизни, ко всей моральной традиции, к нравам и обычаям; подросток от гетерономной моральной психологии переходить к стадии морального аномизма и чистого субъективизма. В отношении к окружающим начинает часто сказываться какое-то нарочитое неуважение, запальчивая небрежность, заносчивость, нередко переходящая в форму навязчивого желания поучать других людей. Подросток преисполнен особой веры в то, что ему удастся то, что не удавалось другим. Игра не выпадает из активности подростка, но принимает уже новый оборот. Игры в техническом смысле слова мало уже привлекают юное существо, быть может, в силу ясного сознания отличия сферы игры и сферы реальности, - но тем сильнее развивается игра в более скрытой и утонченной форме. Не следует забывать, что в это время просыпается сексуальное сознание, вносящее в душу такую неровность, беспокойство, внутреннее возбуждение» (там же. С. 71).

25 Освоение подростками реалистических форм поведения в современной культуре затруднено рядом обстоятельств. Здесь роль искусства и СМИ, стирающих границы между разными реальностями, а также вымыслом и реальностью, приучающих рассматривать виртуальную жизнь 
Стоит отметить и такой момент. В плане образования основная задача сводится пока к освоению «интеллектуальных, телесных и обычных техник». Учащиеся младшей и «первых классов» средней школы учатся правильно читать, писать, рассказывать, считать, решать задачи, рисовать, петь, бегать, прыгать, ходить на лыжах, дисциплинированно вести себя в школе, мыть посуду, забивать гвозди, пилить и пр. Только по мере того, как складывается полноценная личность, учащийся, освоивший техники, начинает в старших классах средней школы самостоятельно мыслить и реализовать себя в разных сферах школьной и внешкольной жизни.

Взрослая культура (фактически две культуры: зрелости и старости, включающей также и пожилой возраст) - это время развития и завериения ставшей личности. Обратим внимание на такую интересную закономерность: если в период становления личности идет освоение техник (семиотических, телесных и обычной техники), то на развитие личности (старшие классы средней школы, высшая школа и работа после школы) приходятся собственно процессы деятельности и мышления ${ }^{26}$. Не означает ли это, что личность выступает как необходимое условие мышления и деятельности (практической, познавательной, художественной и др.)? Забежим вперед, Культурно-исторические исследования, о которых мы будем говорить ниже, подтверждают это предположение. С одной стороны, именно становление личности (т.е. человека разрывающего с традицией, переходящего к самостоятельному поведению,

как обычную, а обычную как виртуальную, здесь новые, допускающие относительность и плюрализм, способы понимания и истолкования жизни, права и морали, здесь и значительно расширившиеся возможности (и соблазны) социальной жизни, наконец, свой вклад в проблему вносит также общее ощущения кризиса современной культуры, не оставившего в стороне как семью, так и буквально каждого человека.

${ }^{26}$ На одном полюсе мышление представляет собой свободный поиск, который мы схватываем, говоря о креативности, на другом полюсе мышление - это действие методов и средств, что нами понимается как мыслительная деятельность. Для деятельности характерны такие механизмы как воспроизводство, трансляция, коммуникация, кооперация позиций, рефлексия. Для мышления - поиск решения проблем и задач, изобретение средств решения, выстраивание дискурсов, реакция на понимание-непонимание. пытающегося выстраивать свою жизнь) в античной культуре потребовало создание «личностно ориентированных практик» (новое судопроизводство, мышление, искусство, платоническая любовь и т.д.), с другой - появление личности и её развитие, в свою очередь, обусловило бурное развитие античной философии, науки, искусства, юриспруденции и прочих социальных практик. Техники могут быть взяты ребенком и подростком, а деятельность и мышление предполагают личность. Два слова, касающиеся образования.

- Образование нельзя понимать как усвоение знаний. Так думают сторонники теории отражения, считающие, что существует неизменный мир, который отражается в знании. Мир, как он дан человеку, порождается в деятельности и изменяется. Отвечая на вызовы времени и новые социальные условия, человек изобретает «семиотические машины» (заданные в языке или схемах системы культурных норм деятельности и мышления). Оестествление и проецирование последних на мир и человека ведут к их новому пониманию и видению, а фактически постепенно способствуют формированию нового мира и человека.

- Образование со стороны включенного в него человека можно понимать как одновременный процесс построения (разворачивания) деятельности и мышления, а также изменения (становления и развития) самого человека.

- Развитие человека процесс дискретный. Подобно превращению гусеницы в куколку и последней в бабочку, человек в своем развитии обновляет несколько раз - один человек в детстве, другой (отрок и юноша) - в юности, третий - во взрослом существовании (причем тоже неоднократно).

\section{Филогенетические аналогии}

Есть такое антропологическое предположение: в онтогенезе ребенок проходит некоторые этапы развития, напоминающие в структурном отношении этапы филогенеза. Не повторяющие буквально эти этапы, а только похожие, поскольку условия становления и развития человечества существенно отличаются от условий становления и развития человека в онтогенезе. Если говорить об этой аналогии (фило и онтогенеза) применительно к нашей теме, то можно с определенной долей условности сравнить детство, во-первых, с самими ранними формами жизни человека, характерными для архаической культуры, во- 
вторых, если иметь в виду завершение детства, отчасти с античной культурой. Архаическая культура была самой первой культурой, существовавшей примерно до 5-4 тыс. до н.э. ${ }^{27}$ Человек архаической культуры считал, что мир населен душами и духами, которые могут выходить из тела или входит в него. Он не отделял себя от примитивного общества (семьи и племени), напоминая в этом отношении ребенка, воспринимающего (осознающего) себя и родителей как одно целое, то, что Выгодский обозначал понятием «прамы». Однако чтобы воспользоваться указанной аналогией применительно к детству, необходимо охарактеризовать особенности архаического человека и его жизни. Попробуем это сделать.

Человек, как известно, социальное существо. Его становление и развитие обусловлено властным воздействием со стороны других индивидов. При этом я показываю, что такое воздействие было опосредовано знаками и схемами (языком) и, что принципиально, подтверждалось использованием техники, которая создается именно в этом процессе древней коммуникации.

На основе знаков и схем в ходе их трансляции складываются знания, которые фиксируют то, что передается ${ }^{28}$. Именно знания являются тем, что для человека задает видение действительности. В свою очередь, получение знания предполагает семиотический процесс (изобретение знаков, означение, действия со

\footnotetext{
27 Представители народов, остановившихся в своем развитии на этапе архаической культуры, называются аборигенами. Изучение последних в антропологии позволило многое понять относительно архаической культуры.

28 «Приступая теперь к исследованию о знаках, пишет один из первых семиотиков св. Августин, я говорю наоборот: пусть никто в них не обращает внимание на то, что [вещи] есть, а только на то, что они суть знаки, т.е. что они означают. Ибо знак есть вещь, которая воздействует на чувства, помимо вида (species), заставляя приходить на ум нечто иное...И у нас только одна причина для обозначения, т.е. для придания знака - вынуть и перенести в душу другого то, что производит в душе то, что создает знак» (Августин А. Антология средневековой мысли. Т. 1. СПб.: РХГИ, 2001. Стр. 66-67). Здесь, как мы видим, двойное понимание: с одной стороны, знак - это то, что обеспечивает трансляцию, с другой - то, что «переносится в душу другого», то есть знание. Слово «слон» - знак, если мы рассматриваем его как средство (орудие), с помощью которого реальное явление фиксируется и затем переносится от одного человека к другому. Но это же слово - знание, если берется как представитель самого реального явления (отчасти, как задающее в коммуникации само явление).
}

знаками). Уже в процессе становления человека, одной из предпосылок которого выступали сообщества человекообразных обезьян, имеющих сильную власть вожака и развитую сигнальную систему, складывается поведение, суть которого представляло коллективное проживание и пере-живание воображаемых событий, заданных знаками ${ }^{29}$. Достаточно развитая форма подобного семиотического освоения действительности неплохо просматривается в архаической культуре. Вот один характерный пример - понимание затмения.

«На языке тупи, - пишет Э.Тейлор, - солнечное затмение выражается словами: «ягуар съел солнце». Полный смысл этой фразы до сих пор обнаруживается некоторыми племенами тем, что они стреляют горящими стрелами, чтобы отогнать свирепого зверя от его добычи. На северном материке некоторые дикари верили также в огромную пожирающую солнце собаку, а другие пускали стрелы в небо для защиты своих светил от воображаемых врагов, нападавших на них. Но рядом с этими преобладающими понятиями существуют еще и другие. Караибы, например, представляли себе затмившуюся луну голодной, больной или умирающей...Гуроны считали луну больной и совершали свое обычное шаривари со стрельбой и воем собак для ее исцеления» ${ }^{30}$.

Обратим внимание, архаические люди в данном случае действуют так, как будто они реально видят «ягуара». Но ведь его нет. Что

29 Человекообразные обезьяны действуют ситуативно: если голодны, ищут пищу, если видят опасность бегут. Но в экстремальных ситуациях, имевших место 1-2 мил. до н.э., они переходили к «парадоксальному поведению», т.е. действовали не в соответствии с ситуацией (например, видя опасность, убегали), а под властным влиянием вожака, который в страхе и помешательстве внушал им с помощью сигналов поведение, не совпадающее с действительной реальностью (скажем, видя хищника, приказывал не бежать, а стоять). Как я показываю, в ситуации парадоксального поведения на основе сигналов складываются знаки, поскольку члены стаи, чтобы удовлетворить требованию вожака, вынуждены перепредставлять реальность и проживать события, заданные не ситуацией, а сигналом, превращающимся в знак. Именно переход к семиотическому поведению, подкрепленный использованием простейшей техники (орудиями) и запустил процесс превращения животных в человека. См. подробнее: Розин B.M. Культурология. Учебник. 2-е изд. М., 2004. С. 107-115; Розин B.M. Человек культурный. Введение в антропологию. М., 2003; Розин B.M. Философия образования. Этюды-исследования (параграф «Каким образом и от кого произошел человек?»). Москва-Воронеж, 2007. С. 158-172.

зо Тейлор Э. Первобытная культура. М., 1939. Стр. 228. 
значит, нет. Нет в физическом смысле, с точки зрения естественнонаучной реальности, о которой дикари ничего не знают. «Ягуар» задан языком, точнее «схемой» и в этом смысле он существует в сознании архаического человека как психическая и семиотическая реальность. Одновременно он подтверждается технически: дикари уверены - затмение прекращается потому, что, так как они стреляют вверх и устраивают шаривари, ягуар пугается и отпускает солнце.

Говоря о знаках, мы употребляем два ключевых слова - «обозначение» и «замещение», например, некоторое число как знак обозначает то-то (скажем, совокупность предметов), замещает такой-то предмет (эту совокупность) в плане количества. У схемы другие ключевые слова - «описание», «средство» (средство организации деятельности и понимания), «образ предмета». Например, схема метро создавалась для упорядочения движения людей, описывает пересадки и маршруты движения, помогает понять, как человеку эффективно действовать в метрополитене; именно схема метрополитена задает для нас образ метро как целого.

Поскольку архаический человек еще не осознает природу схем и не строит их сознательно, лучше подобные семиотические образования назвать «квазисхемами» или «образно-смысловыми синкретами». Квазисхемы в архаической культуре (и в значительной степени и в последующих) задают сразу три грани явления: языковое выражение (нужно было изобрести сам нарратив, например, «ягуар съел солнце» или «луна умирает»), понимание того, что происходит (диск солнца уменьшается, потому что его съедает ягуар), наконец, уяснение того, что надо делать (отгонять ягуара; а там и глядишь, скоро затмение прекращается - ягуap отпускает солнце; то есть архаический человек убеждался в эффективности своих действий и понимания). Изобретаются квазисхемы с целью разрешения «проблемных ситуаций» (преодоления страха, необходимости понимать и действовать). Указанный синкретизм трех образований - языка, коммуникации и деятельности, очевидно, выступает условием разрешения проблем, с которой периодически сталкивались архаические племена (например, когда начиналось затмение, они испытывали ужас и не знали, что делать). Подтверждается существование квазисхем на основе техники.
Первые схемы появляются только в античной культуре. В «Пире» Платон вполне сознательно строит схемы и на их основе дает различные определения любви ${ }^{31}$. Схемы в отличие от квазисхем строятся сознательно и отрефлексированы, естественно в той форме, которая доступна соответствующему времени. Анализ «Пира» показывает, что схемы не только позволяют получить новые знания и задают новую реальность любви, но и по-новому организуют жизнедеятельность человека. Он теперь не ждет, пока у него возникнет страсть неизвестно к кому, поскольку так захотели боги любви, а ищет свою половину (для этого, кстати, нужно понять, кто ты есть сам), «вынашивает духовные плоды», стремится к прекрасному, благу и бессмертию. При построении схем Платону приходится преодолевать непонимание слушателей, пересматривать и уточнять схемы с тем, чтобы они выглядели убедительными. Судя по всему, Платон ориентируется, прежде всего, на тех продвинутых членов античного полиса, которые почувствовали себя личностями (античная личность, которая складывается в этот период - это человек переходящий к самостоятельному поведению и выстраивающий свою жизнь).

Схему можно определить таким образом: это двуслойное предметное образование, где один слой (например, образ ягуара) замещает другой (то, что происходит с солнцем). Схемы выполняют несколько функций: разрешают проблемную ситуацию, помогая понять происходящее, организуют и переорганизуют деятельность человека, собирают смысль, до этого никак не связанные между собой, способствуют выявлению новой реальности. Необходимым условием формирования схем является означение, то есть замещение в языке одних представлений другими. Однако главное в схемах - не возможность действовать вместо обозначаемого объекта, а задавать новое видение и организовывать деятельность. Если мы делаем акцент на новом видении, то знаковая функция схемы выступает

\footnotetext{
${ }^{31}$ Например, одно из определений любви, как поиск своей половины, Платон задается на схеме андрогина. Устами одного из участников диалога Аристофана Платон излагает правдоподобный миф о происхождении людей разного пола из монстров-андрогинов, существ, соединявших в себе признаки мужского и женского полов. Разгневовшись на андрогинов, Зевс разрезает их на половинки, но каждая половина, олицетворяющая возлюбленного, начинает искать другую свою половину.
} 
только как условие схематизации. Схемы подтверждаются техникой, в роли которой выступают как орудия, так и новая, опирающаяся на схемы, деятельность человека. Ниже мы будем говорить о той важной роли, которую в детстве играют схемы.

Становление человека в культуре происходит одновременно с самой культурой. В этом плане разрешение проблемных ситуаций шло по двум основным направлениям: с одной стороны, формируются «базисные схемы», задающие основную реальность культуры, с другой - «социальные практики», направленные на человека, и внутри них сам человек данной культуры. Например, в архаической культуре параллельно формированию представлений о душе (духах), семье, племени, охоте и собирательству складывались архаические практики захоронения, лечения, толкования сновидений, вызывания душ, общения с ними (жертвоприношения, просьбы, угрозы и прочее), брачных отношений, инициации и ряд других, подробно рассмотренные в культурологической литературе. Заметим, все эти практики были коллективные, человек в них не только участвовал, но и одновременно выступал объектом (его хоронили, лечили, толковали его сны, проводили через инициацию и т.д.). Всего один пример.

«Важнейший и наиболее образцовый переходный обряд - инициация, - пишет E.M. Мелетинский, - отрывающая юношу, достигшего половой зрелости, от матери и сестер, от группы непосвященных женщин и детей, и переводящая его в группу взрослых мужчинохотников с последующим правом женитьбы и т. д. Этот переход включает физические испытания на выносливость, мучительную посвятительную операцию и овладение основами племенной мудрости в форме мифов, инсценируемых перед посвящаемыми. Инициация включает также символическую временную смерть и контакт с духами, открывающий путь для оживления или, вернее, нового рождения в новом качестве. Символика временной смерти часто выражается в мотиве проглатывания его чудовищем, посещения царства мертвых или страны духов, борьбы с духами, добывания там ритуальных предметов и религиозных тайн» ${ }^{32}$. Включенный в эти процедуры юноша должен был строго соблюдать все «предписания» обычая; он не был волен не только что-либо изменять из

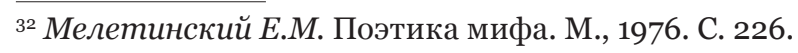

заведенного, но даже желать что-нибудь, не укладывающееся в процесс инициации.

Согласимся, человек не пассивное существо, он активен и действует осмысленно. Поэтому включение человека в архаические практики, предполагало для него соответствующее этим практикам осмысление действительности, включая самосознание. Другими словами, как необходимое условие становления перечисленных архаических практик выступает формирование представлений о душе, смерти, болезни (здоровье-нездоровье), снах, брачных отношениях, уподобленных охоте, проведении человека в период инициации через смерть и прочее. То же самое можно сказать и иначе: психические феномены архаического человека - прежде всего его представления о собственной душе, теле, сновидениях, смерти являются артефактами и формируются в ответ на архаические практики. Два механизма, как можно понять из нашего анализа, обеспечивают становление этих феноменов: изобретение соответствующих схем и самоорганизация психики.

Остановимся, например, более подробно на понимании архаической души. Изобретение представления о «птичке» (этимология слова душа и птица совпадают у древних народов), в которой сосредоточена жизнь человека, которая живет в теле и может из него выйти (вылететь), но и вернуться назад, то есть представления о душе, с семиотической точки зрения, представляет собой создание квасхемы. С психологической же конституирование новой реальности. Схема души обеспечивает склейку двух предметных реальностей (поведения птички и человека), так что одна представляет другую; эта схема дает возможность различить разные состояния человека (которые и получают названия - смерти, болезни, сновидения и пр.) и организовать на их основе соответствующие коллективные действия (в результате начинают складываться архаические практики). Необходимое психологическое условие становления такой схемы - связывание в одной целое через механизм означения и синтеза представлений о птичке и человеке. Реальность души формируется в рамках этого целого.

Поскольку все архаические практики в той или иной степени строятся на основе представления о душе, конституирование представлений архаического человека о самом себе полностью определяется анимистическим мироощущением. Вслед за реальностью души архаический человек открывает (начи- 
нает различать и переживать) у себя соответствующие душевные состояния: въход души из тела или проникновение в тело чужой души (то, что для нас выглядит как болезнь, слабость, головная боль, головокружение, обморок, смерть); возвращение души в тело (соответственно, выздоровление или состояния, которые мы называем “проснулся”, “очнулся”, “обрел сознание”, “пришел в себя”, “стало лучше”, “ушла боль” и т. д.), встреча с душой (дyхом) (пример - рассматривание и переживание архаическим человеком наскального или скульптурного изображения человека или томемного духа) ${ }^{33}$.

Так как в архаической культуре вся жизнь понимается (истолковывается) анимистически, и все другие состояния человека, например, ощущения во время еды, полового общения, усталость или, наоборот, легкость после сна или отдыха, страх, радость и т. д. тоже получают анимистическую окраску. Например, страх понимается и ощущается как приближение опасной чужой души или стремление собственной души покинуть тело (известное выражение “душа ушла в пятки” относится как раз к последнему случаю).

Намеченная здесь логика становления человека в архаической культуре в значительной степени сохраняется и для культуры древних царств. Только здесь на место базисной схемы души приходит другая схема - представление о богах, которым подчиняются не только люди, но и их души ${ }^{34}$. Наряду с рядом практик, перешед-

33 В каждом культурном регионе указанные состояния архаического человека понимались и переживались несколько по-разному в соответствии с конкретной историей и условиями социальной жизни данного региона. Например, в Тибете умирание и сейчас понимается так же, как и много тысяч лет тому назад. Но есть одна особенность: оказывается душа сама не может покинуть тело. Чтобы душа вышла в правильном месте, через макушку, лама, глубоко сосредоточившись, должен отождествить себя с покойником и за него сделать усилие (одновременно произнося магические слова “хик” и “пхет”), которое бы заставило душу пробить для себя в темени выход. Исключение, посвященные. Они «могут самостоятельно осуществить восхождение своего духа к макушке головы, и, чувствуя приближение конца, самим для себя произнести освободительные "хик" и “пхет". Таким способом они могут даже совершить самоубийство, и, если верить молве, такие случаи действительно бывают» (Дэвид-Ниль А. Мистики и маги Тибета. “Васанта”. 1992. С. 23-24).

${ }^{34}$ Как я показываю, переход в культуре древних царств к интенсивному земледелию потребовал разделение труда и коллективные формы деятельности с жестким вертикальным управлением. Схема души уже ших из архаической культуры (но, естественно, видоизмененных), таких как захоронение, лечение, толкование сновидений, вызывание душ и духов, в культуре древних царств формировались и новые, например, практика общения с богами (мистерии встречи богов, совместная деятельность человека с богами, приношение богам жертвы и прочее), расчет судьбы человека, определение плохих и хороших дней для работы, сражений и других дел.

Хотя человек уже вполне осознавал свою индивидуальность (ее выражала идея судьбы), он не считал, что его я - это центр, в котором сосредоточена его воля и жизнь. Жизнь человека находилась в руках богов, а воля помогала только в том случае, если совпадала с волей богов. И состояния индивида осознавались в той же логике: они определялись взаимоотношениями человека с богами. Например, болезнь возникает не от собственного тела или души человека, а потому, что боги не закрыли дорогу (врата души) демонам; в свою очередь, последнее случилось потому, что боги были заняты более серьезными делами или по какой-либо причине (данный имярек не принес жертву, не подчинился и т. п.) разгневались на человека. Если современный человек часто ощущает свое Я как центр мира, то для человека культуры древних царств топология мира задавалась всем пантеоном богов, то есть ощущалась именно как сакральный космос; Я отдельного человека в этом космосе воспринималось как простая точка.

Да, человек культуры древних царств осознавал свою индивидуальность, имел собственную судьбу, а ряде случаев, как писали поэты и ученые Нагуа «сам себе выговаривал и дела его шли хорошо». Но в данном случае индивидуальность - это была всего лишь вариация на общую тему, заданную единым базисным культурным сценарием, общими и одинаковыми представлениями о мире и человеке.

не могла обеспечивать эти более сложные виды деятельности. Возникшие проблемы, например, почему нужно было действовать коллективно, подчиняться царям и жрецам, отдавать другим значительную часть созданных продуктов, были разрешены путем «открытия» богов, которые создали мир и человека, поддерживали и направляли его, различались так сказать профессионально (боги войны, народа, разных видов мастерства - бог-кузнец, бог-гончар, богкирпичей и пр.), были бессмертны. Другими словами, языческие боги - это новая схема, обеспечивающая действия человека в условиях разделения труда и коллективной, управляемой деятельности (см. Розин B.M. Культурология. Учебник. М., 2003-2004; Розин B.M. Теория культуры. М., 2004). 
Все люди, и последний раб и цари, верили в богов и считали, что те создали мир и определяют всю жизнь человека. Хотя активные и умные люди пытались повлиять на богов, чтобы склонить их к лучшему к себе отношению, они, тем не менее, ни в коей мере не подвергали сомнению саму веру в богов или заданное теми устройство мира.

Только в античной культуре формируется новый антропологический тип - личность. Спрашивается, каким образом, ведь в архаической культуре и культуре древних царств самостоятельное поведение не допускалось вообще, поскольку оно ослабляло социум? Человек мифической эпохи, пишет К.Хюбнер, находит корни своей жизни в совместном бытии. «Как единичное, как индивид и Я он ничего собой не представляет <...> Не иметь рода значит быть лишенным нуминозного Kydos и Olbos, в которых содержится даваемая богами идентичность рода, то есть вообще не иметь своего лица <...> Человеку мифической эпохи абсолютно неизвестна область внутренне идеального в качестве Я. Он есть тот, кто он есть, занимая при этом место во всеобщей мифическинуминозной субстанции, которая существует во многом, будь то люди, живые существа или “материальные” предметы, поэтому и человек живет во многом, и оно живет в нем» ${ }^{35}$.

Может ли индивид, идентифицирующий себя с родом, рассматривающий любое самостоятельное действие как нарушение табу и усилия, не поддержанные сакральными силами, естественным путем превратиться, перерасти в личность? Вряд ли. Но как тогда можно объяснить появление личности?

Современные культурологические и историко-психологические исследования показывают, что личность довольно позднее образование. В филогенезе она складывается не раньше античной культуры, а в онтогенезе только в подростковом возрасте, когда взрослые, посылая ребенка в школу, начинают склонять его к самостоятельному поведению. Можно говорить о двух основных предпосылках становления личности в культуре: 1) переносе индивидом сложившегося в социуме способа управления другими на самого себя («возможности самому себе выговаривать») и 2) кризисе религиозных представлений, на которых держалась вся культура древнего мира. Человек уже не может рассчитывать на богов, мироздание рушится, он остается один на один с собой. А это, как известно, - одно из

\footnotetext{
${ }^{35}$ Хюбнер К. Истина мифа. М., 1996. С. 108.
}

условий рождения индивидуальности и личности человека. Если человек не может опираться на богов, он начинает искать опоры в себе (в своей душе) и вне себя - в поддержке других людей.

В результате в античной культуре, где, как известно, мифологические и религиозные начала сильно ослабевают, а государство имеет ограниченное влияние на человека, складывается первая в истории человечества личность. В теоретическом же плане можно говорить о формировании самостоятельного поведения и самодетерминации жсизни (т.е. попыток самостоятельно выстраивать собственную жизнь). С новым мироощущением человека можно познакомиться в текстах Платона.

Вспомним, поведение Сократа на суде. С одной стороны, он идет на суд и соглашается с решением общества, назначившим ему смерть. С другой - Сократ предпочитает оставаться при своем мнении. Он твердо убежден, что его осудили неправильно, что, «смерть - благо» и «с хорошим человеком ничего плохого не может быть ни здесь, ни там, и что боги его не оставят и после смерти» ${ }^{36}$. Сократ как становящаяся личность, хотя и не разрывает с обществом, тем не менее, идет своим путем. И что существенно, не только Сократ выслушивает мнение суда, то есть общественное мнение, но и афинское общество выслушивает достаточно неприятные для него речи Сократа и даже, как нам известно, через некоторое время начинает разделять его убеждения. Отчасти Сократ уже осознает свое новое положение в мире. Например, он говорит на суде, что ведь «Сократ не простой человек», а также, «где кто поставил себя, думая, что для него это самое лучшее место <...> там и должен переносить опасность, не принимая в расчет ничего, кроме позора, - ни смерти, ни еще чего-нибудь» ${ }^{37}$. На излете античности Сократу вторит Апулей. В «Апологии или Речи в защиту самого себя от обвинения в магии» он так формулирует кредо своей жизни - «Не на то надо смотреть, где человек родился, а по каким принципам решил он прожить свою жизнь ${ }^{38}$.

Здесь принципы типа «человек сам определяет свою жизнь» или «сам определяет принципы, по которым будет жить» выполняли двоякую роль: обеспечивали (организовывали)

${ }^{36}$ Платон. Апология Сократа // Платон. Соч: В 4 т. T.1. M., 1994.

${ }_{37}$ Там же. С. 82.

${ }^{38}$ Апулей. Метаморфозы в XI книгах. М., 1960. С. 28. 
самостоятельное поведение и задавали новое видение действительности, включавшее в себя два важных элемента - индивидуальное видение мира и ошуцение себя микрокосмом. Индивидуальное видение мира было необходимо, поскольку, действуя самостоятельно, личность не только реализовала себя, но и должна была опираться на реальность вне себя (в противном случае она бы выпала из общества, не смогла жить в мире, погибла) ${ }^{39}$.

Интересно, что становление античной личности происходит одновременно с формированием «личностно ориентированных практик» - античного судопроизводства, театра, любви, собрания философов (академий). И это не случайно. Именно на сцене суда, театра или академии античное общество рассматривает и осмысляет такой странный феномен как человека, живущего не по традиции, а последний объясняет обществу, как он дошел до жизни такой и почему иначе жить не может. В произведениях Әсхила, Софокла, Еврипида и других известных греческих драматургов герои ставятся в ситуацию, где они вынуждены принимать самостоятельные решения и при этом, как показывает А.Ахутин, обнаруживают свою личность.

Античная личность складывается, в попытке разрешить следующее противоречие: человек должен действовать в соответствии с традицией и не может этого сделать, поскольку нарушит традицию. В этой драматической ситуации он вынужден принимать самостоятельное решение, тоже нарушающее традицию. Так вот суд и театр (позднее платоническая любовь и мышление) оказываются той формой, в которой вынужденный самостоятельный поступок героя получает санкцию со стороны общества. Одновременно, формой становления личности и его сознания. Не то чтобы общество оправдывает поступок героя, оно осмысляет этот поступок, переживает его, вынуждено согласиться, что у героя не было

\footnotetext{
39 В культурах, предшествующих античности, человеку не нужно было думать, как действовать в определенных ситуациях. Все они были известны коллективу, известно было и как в них действовать. Если же человек разрывает с традицией и живет посвоему, ему нужна опора и указания. Ими становится, с одной стороны, индивидуальное видение реальности; эту реальность, мир личность открывает (с теоретико-деятельностной точки зрения, открытие невозможно без полагания и конструирования этой реальности). С другой стороны, - самосознание: личность открывает себя, причем именно в рамках индивидуального видения реальности.
}

другого выхода. В указанных личностно ориентированных практиках происходит адаптация личности к обществу и наоборот, а также формирование сферы реализации личности ${ }^{40}$.

Можно высказать и такой тезис: складываются не только личность и личностно ориентированные социальные практики, но и общество. Именно выработка отношения к нарождающейся личности способствует кристаллизации и консолидации общества. Личность как целое предполагает и целостное отношение к личности общества. Анализ платоновской «Апологии Сократа», показывает, что античная личность «потянула» за собой и формирование ряда социальных субъектов (на их основе дальше формируются профессиональные сообщества).

Теперь такой вопрос: каким образом античная личность взаимодействует с другими личностями и обществом, если учесть, что каждый видит все по-своему? Например, средний гражданин афинского общества думает, что жить надо ради славы и богатства, а Сократ на суде убеждает своих сограждан, что жить нужно ради истины и добродетели. Этот средний афинянин больше всего боится смерти, а Сократ доказывает, что смерть - скорее всего, благо. Мы видим, что основной «инструмент» Сократа - рассуждение. С помощью рассуждений Сократ приводит в движение представления своих оппонентов и слушателей, заставляя меняться их видение и понимание происходящего, мира и себя. Так Сократ сначала склоняет своих слушателей принять нужные ему знания типа (например, то, что смерть есть или сладкий сон или общение с блаженными мудрецами), а затем, рассуждая, приводит слушателей к представлениям о смерти как блага.

Другими словами, рассуждения - это инструмент и способ согласования поведения индивидов при условии, что они стали личностями и поэтому видят и понимают все посвоему. Именно для этой цели они и были изобретены. Параллельно рассуждения вводят в оборот и определенные знания (утверждения о действительности), которые по своей социальной роли должны обладать свойством прагматической адекватности (истинности). То есть рассуждения выполняют две основные функции: дают знания, адекватно отображающие действительность и обеспечивают реализацию личности как в отношении ее самой («персональная реальность»), так в отношении других

40 Ахутин А. В. Открытие сознания // Человек и культура. М., 1990. С. 20-21. 
и социума (этот аспект социальной реальности мы сегодня относим к коммуникации)

Дальше, однако, возникли проблемы: рассуждать можно были по-разному (различно понимать исходные и общие члены рассуждения и различно их связывать между собой), к тому же каждый тянул одеяло на себя, то есть старался сдвинуть представления других членов общества в направлении собственного видения. В результате, с одной стороны, парадоксы, с другой - вместо согласованного видения и поведения - множество разных представлений о действительности.

Из истории античной философии мы знаем, что возникшее затруднение, грозившее парализовать всю общественную жизнедеятельность греческого полиса, удалось преодолеть, согласившись с рядом идей, высказанных Платоном и Аристотелем. Эти философы предложили, во-первых, подчинить рассуждения законам (правилам), которые бы сделали невозможными противоречия и другие затруднения в мысли (например, рассуждения по кругу, перенос знаний из одних областей в другие и др.), во-вторых, установить с помощью этих же правил контроль за процедурой построения мысли. Чтобы применить правила к конкретному случаю, Аристотель создает категории и понятия.

Создание правил мышления, категорий и понятий, позволяющих рассуждать без противоречий и других затруднений, получать знания, которые можно было согласовывать с обычными знаниями, обеспечивая тем самым социальный контроль, а также понимать и принимать все предложенные построения (правила, категории и понятия), венчает собой длительную работу по созданию мышления. С одной стороны, конечно, мыслит личность, выражая себя в форме и с помощью рассуждений (размышлений). С другой - мышление, безусловно, представляет собой общественный феномен, поскольку основывается на законах социальной коммуникации и включает в себя стабильную систему правил, категорий и понятий.

\section{Особенности кулътуръ детства}

\section{Выбор человеческого пути становления и развития}

У родившегося ребенка нет (как было у человекообразных обезьян) в запасе одного, двух миллионов лет и множества экстремальных ситуаций для превращения в человека. Но ре- бенок активен и у него есть любящие родители, которые сразу же включают его в стихию языка и общения. В каком отношении ребенок активен? Ну, с одной стороны, естественно в удовлетворении своих физиологических желаний, с другой - в расширении области переживаемых событий, источником который выступают те же самые родители. Но родители пока составляют с ребенком одно биологическое и психическое целое; здесь еще нет двух субъектов. Вот мама улыбается двухнедельному или двухмесячному (неважно) сыну, и чудо он тот час же тоже расплывается в улыбке. Современные психологии хватаются за голову, и начинаются фантазии: ребенок подражает матери, он чуть ли не личность ${ }^{41}$.

Ничего подобного, возразил бы Л.С. Выготский, просто ребенок и мать - одно целое, прамы. А я бы добавил: ребенок улыбается не потому, что у него уже есть эмоции и он комуто подражает, а потому, что как составляющая целого (прамы) ведом другой составляющей этого целого (улыбкой матери). Наш оппонент, естественно, задаст вопрос, каким образом ведом (управляем), укажите механизм. Честно отвечу: не знаю, каким образом, а тем более механизм, но уверен, что рассуждаю правильно. А следовательно, теперь, кого это интересует (меня не очень), может поискать и поизучать и механизм.

Если ребенок ловит улыбку (одновременно и свою и матери), - как, тоже не знаю, но можно предположить, что посредством зрения и внутреннего ощущения - то вот одно из первых событий. Активность ребенка, на мой взгляд, состоит в том, что он ловит событие, переживает его и получает от этого удовольствие, поскольку мир, в котором он находится и живет, расширяется и обогащается. Очень скоро именно желание получать удовольствие за счет переживания событий и расширения мира становится основой ориентации и стимулом активности ребенка (возможно, эта основа и есть то, что мы называем интересом). И пошло-поехало: игрушки, звуки речи, руки родителей, положения собственного тела, а потом и сами родители и сам ребенок - все становится событиями жизни ребенка.

\footnotetext{
${ }^{41}$ Пример, знаменитая статья Мильзоффа, в которой обсуждается феномен «имитации у новорожденных». Meltzoff, A.N., \& Moore, M.K. (1977). «Imitation of Facial and Manual Gestures by Human Neonates.». Science, vol. 198, 1977. p. Meltzoff, A.N., \& Moore, M.K. (1977). «Imitation of Facial and Manual Gestures by Human Neonates.». Science, 198, 75-78.75-78.
} 
Ну а слова, которые с нежностью произносит мать (отец или бабушка с дедушкой), как они воспринимаются? Как события, но слитые в рамках прамы с родителями, неотделимые от них. Однако, где-то после года (у кого как), ребенок совершает гениальное открытие: он обнаруживает сначала, что предметы и звучания слов могут составлять самостоятельные события, а потом, что к предмету можно перейти через определенное звучание слова. Точнее, что звучание слова и есть этот предмет, но несколько отличный от прежнего. То есть появляется значение слова, образуется знак. В данном случае я могу даже рассказать о механизме этого процесса. Но сделаю это не на материале слова, а рисунка.

Я рисую своей полуторогодовалой дочери красное солнце и говорю: «смотри солнце, красное, круглое». И вижу, что она ничего не понимает: не видит в красном пятне на бумаге солнца. Я задумываюсь: ну, да нее солнце на небе, слепящее, а тут ее обманывают, показывая на какое-то пятно на бумаге. Я не знаю, что делать, продолжаю настаивать, показываю красное пятно, и говорю, что это солнце. И, вдруг, через пару недель (у детей всегда - вдруг, что-то меняется, и непонятно почему), я понимаю, что моя Лена видит в рисунке солнце. И вспоминаю, кстати, что вчера я показывал ей, как садилось солнце, и еще сказал: «смотри Леночка, какое солнце красное и круглое, как на бумаге». Вспоминаю еще свои исследования визуального восприятия, где я утверждал, что человек может реализовать (актуализировать) опыт восприятия определенного предмета не только на материале этого предмета, но и на материале его рисунка, а также в период сновидения без всякого визуального материала ${ }^{42}$. Тогда понятно, что произошло. Лена знает, что если папа говорит: смотри солнце, то значит, оно должно быть. Эта установка рано или поздно обусловливает то, что опыт восприятия солнца реализуется на материале красного пятна. В этот момент она начинает видеть в красном пятне солнце, но, конечно, не обычное, а, так сказать, «рисуночное». Аналогично, родители склоняют своего ребенка начинать видеть и слышать в слове то, что оно обозначает ${ }^{43}$.

\footnotetext{
42 Розин В.M. Визуальная культура и восприятие. Как человек видит и понимает мир. Изд. 5. М,. 2012.

43 Кто-то может возразить, обратив внимание, что моя дочь усваивала значение изображения солнца, уже опираясь на язык (зная, что обозначает слово «солнце»). А вот, спрашивается, каким образом дети усваивают значения самого первого слова?
}

Это, как говорит Штерн, «величайшее открытие» на много порядков расширяет событийную реальность ребенка, поскольку он научается порождать события, а также связанные с ними все новые и новые предметы, двигаясь в языке. Правда, необходимое условие этого расширения и вхождения в новый «языковой мир»- освоение техники осмысленного говорения (запоминание значений предметов, умение их называть, составление из звуков слов и прочее).

Понятно, к чему я клоню: именно образование знаков (значащих слов, а позднее и других семиотических образований, например, изображений или музыкальных выражений) выводит ребенка из животного состояния на широкую дорогу человеческой жизни ${ }^{44}$. Постепенно (на это уходит два-три года и дальше продолжается у некоторых всю жизнь) ребенок осваивает знаковые системы и весь мир для него преображается. Все предметы, в том числе и он сам, теперь имеют имена, неозначенные, как бы сказал Кант, представляют для ребенка «вещи в себе», а попросту не существуют, всякая незнакомая вещь взывает

Думаю, примерно также. Здесь колоссальную роль играют родители. Как составляющая прамы они способствуют тому, что ребенок актуализует сложившийся психический опыт на новом материале - звучащем слове.

Интересно, что подобные вопросы о начале чегото иногда задают и сами дети. Корней Чуковский в книге «От двух до пяти» приводит, например, следующие вопросы детей: «Как сделался первый человек? Ведь его родить-то было некому!». «У кого самая первая мама сисю сосала?» http://www.litmir. net $/ \mathrm{br} / \mathrm{?b}=72192$

44 «У нас, взрослых, наша психическая жизнь так интимно и глубоко связана с языком, что мы готовы считать его чем-то вроде «врожденной» нами функции. Между тем развитие в нас речи связано с длительным и сложным процессом, в котором дитя постепенно научается владеть формами того языка, в атмосфере которого оно созревает. Мы застаем, при нашем вступлении в жизнь, готовый и сложившийся язык, которым мы должны овладеть, чтобы стать психически зрелыми, чтобы войти в живое общение с людьми, нас окружающими. Нам дается в языке богатейшее «социальное наследство», но мы должны им овладеть, и лишь в той мере, в какой это удается нам, мы можем пользоваться социальным наследством. Процесс усвоения наследуемого материала не только не сосредоточен в один момент, не только растянут на продолжительное время, но он вообще не имеет пассивного характера (как в биологическом наследовании), а наоборот предполагает со стороны растущей личности творческую активность» (Зеньковский В. Цит. соч. С. 43). 
о своем имени, которое с помощью родителей тут же и обнаруживается. Именно родители как составляющая прамы обеспечивают жесткое нормативное освоение ребенком значений знаков и способов оперирования с ними.

\section{Родители в роли языческих богов и «социального тела» ребенка}

Здесь уже наоборот можно говорить об онтогенетических параллелях относительно филогенеза. В этом отношении, конечно, родители только напоминают для ребенка богов. Стоит отметить, что и структура прамы меняется на этом втором этапе, начиная от полутора, двух лет развития и дальше. А именно, ребенок уже различает себя и родителей, но осознает себя вместе с родителями, подобно тому, как архаический человек, конечно, осознавал себя, но вместе с семьей и племенем.

«У ребенка, - пишет Зеньковский, - никогда не бывает того только внешнего материала, с которым оперируют психологи, обсуждающие вопрос о том, как сознаем мы чужую душевную жизнь. Для ребенка живые люди с самого начала суть «одушевленные» существа, т. е. полные жизни и активности, творческой инициативы, - чисто внешними проективные образы никогда для ребенка не бывают. Даже фотографические снимки, свои отражения в зеркале дитя долго принимает за живые существа... Чужая, «одушевленность» трактуется, конечно, очень примитивно, как способность к реакциям, к активности, но никогда дитя не проходит той стадии, которую выдумали психологи, отрицающие непосредственное сознание жизни в других людях, - стадии, при которой сначала выступает лишь чисто внешний материал, а затем этот материал, с помощью тех или иных процессов, одухотворяется и одушевляется <...> Конечно, у ребенка всегда есть непосредственное чувство своей «одушевленности»; дитя непосредственно чувствует себя, как живое, активное существо, непосредственно чувствует в себе пульс жизни. Но такое непосредственное чувство не означает, что дитя “думает” о себе, - да оно и не имеет никакого мотива “думать” о себе, никакого интереса к себе. Первые мотивы к тому, чтобы останавливаться на самом себе, чтобы выходить за пределы непосредственного чувства своей личности, даются социальной средой. Дитя очень рано привыкает к тому, что оно имеет свое особое имя, рано научается «откликаться» на него, - поворачивать голов- ку, поднимать глазки, улыбаться. Еще дальше оно привыкает к определенным действиям в отношении к себе - со стороны матери, няни, окружающих людей... Проективная самохарактеристика, которую можем иначе назвать социальным самосознанием, никогда не исчезает в нас, но образует устойчивый и неустранимый полюс в нашем самосознании. И мы, взрослые, постоянно обращаемся к самим себе так, как к нам должны были бы обращаться другие люди. Кто не знает таких форм обращения к самому себе, когда человек говорит себе (как если бы говорил ему кто-либо чужой): “ну, Петр Петрович, пора тебе приниматься за работу” <...>

Эти случаи расхождения данных внутреннего опыта и внешней его оценки все чаще имеют место (когда дети подрастают, взрослые становятся менее к ним внимательны), все чаще сознаются детьми, и, по мере их накопления, дитя приходит, наконец, к чисто субъективному самосознанию, к сознанию своих желаний, замыслов, чувств, мыслей. Здесь дитя осознает в себе свой внутренний, непосредственно недоступный другим людям мир, - сознает, конечно, лишь частично, но все же в подлинном смысле открывает самого себя для себя. Вначале субъективное самосознание слагается из сравнительно небольшого материала, который еще противоставляется другим переживаниям. Мы увидим, что настоящий интерес к самому себе созревает очень медленно и становится вполне определенным лишь в третьем периоде детства (отрочестве), но, конечно, как новый полюс в самосознании внутренний мир выступает очень рано» 45 .

Отношения ребенка с родителями (и другими взрослыми, например, воспитателями в детском саду) двояки: с одной стороны, родители по-прежнему ведут и направляют ребенка (здесь они похожи на богов, демиургов), с другой - ребенок все чаще использует своих родителей для решения тех задач, которые он еще не в состоянии решить. Пользуясь их силой и умом, ребенок расширяет свои возможности. Правда, начинается это еще в предыдущем периоде. Вот скажем, ребенок замечает, что оброненную им игрушку мать приносит назад в манеж. И скоро ребенок сознательно выбрасывает игрушку из манежа, заставляя мать приносить её вновь и вновь. В данном случае он не только расширяет свою реальность, но и постепенно уясняет, что матерью

45 Зеньковский В. Цит. соч. С. 46-48. 
можно управлять. И кстати, получает от этого, судя потому, что каждый раз смеется, большое удовольствие.

Дальше больше: ребенок заставляет родителей (применяя широкой диапозон средств: плач, скандал, нытье и пр.) выполнять свои желания. За счет родителей он расширяет свои возможности и способности, подобно тому, как мы расширяем их за счет техники, социальных институтов, общения. Другими словами, родители становятся социальным телом ребенка и в некоторых случаях чуть ли не до их смерти. Здесь может встать естественный вопрос: не способствует ли подобное развитие событий развитию детского эгоизма? Естественно, способствует, особенно, если родители идут на поводу у ребенка или пытаются быстрее выполнить его желание, чтобы самим стать свободными. Но никак не способствует, если родители ограничивают выполнение просьб ребенка только теми, которые необходимы для его пользы и развития. Да, при этом они перестают быть социальным телом своего ребенка, но не вообще, а лишь в зоне опасного развития.

Но развитию эгоизма ребенка может способствовать, и даже очень, и демиургическая позиция родителей. К сожалению, наши родители сами часто являются эгоистами; в этом случае они невольно прививают эгоизм и своим детям. Известный философ и культуролог Светлана Неретина характеризует нашу эпоху как внеэтическую, а, следовательно, в той или иной мере эгоистическую. «Процессы, ныне происходящие, можно назвать постхристианскими и потому, что мы вступили в мир этики, точнее не - или внеэтики, хотя бы потому, что XX век является веком, когда киллерство стало профессией» ${ }^{46}$.

Но что понимается под эгоизмом? Не просто себя-любие или эгоцентричность по Пиаже, и то и другое для человека, вероятно действительно, было характерным всегда, начиная с античной культуры. Речь идет о другом. О тех периодах в истории нашей цивилизации, когда перестают работать традиционные представления о реальности и привычные социальные нормы поведения, и человек вынужден заново во всем этом устанавливаться. При этом, как правило, он во многом начинается опираться на самого себя, т.е. действует эгоистически, что и приводит, как говорил Платон, к «войне всех против всех», к разного рода социальным конфликтам. Для России эта ситуация особенно драматична, посколь-

\footnotetext{
${ }^{46}$ Неретина C.C. Точки на зрении. Санкт-Петер-
} бург, 2005. С. 273. ку, с одной стороны, были разрушены социалистические представления и ценности, а с другой - нам вменяют западные капиталистические и либерально-демократические картины мира и представления, которые сами переживают глубокий кризис.

Для современного эгоизма характерно то, что многие его представители уверены, что они самые обычные люди, не эгоисты, а часто даже альтруисты, работающие на общее благо. Сотрудники международных корпораций, эксплуатирующих местное население, не сомневаются, что их корпорации, конечно, же для этого населения благо, поскольку дают работу и несут цивилизацию; российские чиновники, попирающие права своих граждан и берущие взятки, считают, что только так и можно управлять нашим темным населением и жадным бизнесом, что все это на пользу обществу. Как никогда прежде, относительно современности справедлива формула, что дорога в ад вымощена благими намерениями.

\section{Ребенок осваивает взрослый мир посредством игры, «мыслит» схемами}

Как бы ни понимать детство, нужно признать, что оно не состоялось бы без взрослых и педагогов, которые признали своеобразие детского развития и пошли на то, чтобы создавать для детей специальные условия (не включать их во взрослый труд, что широко практиковалось еще в средние века, предоставить им свободное время, организовать приемлемую среду - «детский сад»). Тем самым взрослое общество и мир, как бы противопоставили себя детям, а последние смогли не только отчасти жить по-своему (играть, общаться друг с другом), но и попали в мир, разделенный как бы на два государства - взрослый мир и детский. Поскольку дети понимают, что когда-нибудь вырастут, да и взрослые направляют их к своему миру, и поскольку взрослый мир на порядок богаче и интересней детского, почти все дети рано или поздно хотят жить взрослой жизнью и попасть в него. Интерес к взрослой жизни у детей подогревается и языком. Дело в том, что все, что есть в языке, для человека, особенно для детей, требует своего реального воплощения, не обязательно материального, но лучше именно такое ${ }^{47}$.

47 Особенно в современной культуре, где самые необычные идеи, например, мир мамонтов или дино- 
Указанное обстоятельство плюс преображение мира, о котором мы говорили выше в связи с развитием языка (знаковых систем), а также трансформация прамы, позволяющая ребенку осознавать себя и родителей, имеют два очень важных последствия. Во-первых, ребенок постепенно расширяет зону свободы, т.е. собственной активности. Во-вторых, он начинает осваивать мир взрослых. С одной стороны, ребенок пытается этот мир понять, с другой - жить его событиями ${ }^{48}$. Но поскольку он ребенок и события взрослого мира ему не подчиняются, а родители отказываются помогать в экспансии своего мира, постольку ребенок (кстати, тоже с помощью взрослого) создает свой собственный мир. Это мир игры, сказок, детского воображения и дискурса. Рассмотрим для примера детскую игру и воображение.

Вот известная всем с детства игра в лошадку. Ребенок садится на палочку, трясет головой как лошадка, «ржет», «скачет», «ест тра-

завров, сначала реализуются в исследованиях (знаниях), потом в телевизионных фильмах, затем в пространстве виртуальных реальностей (3-4 D), а следующий этап - материальное воплощение (скажем, уже обсуждается возможность клонирования мамонтов). Но эта история с реализацией и материальным воплощением семиотических значений началась еще в архаической культуре. Например, смерть понималась не только как уход души из тела, но и как создание «домов» (могил) для ушедшей души, куда клались все предметы и оружие умершего, чтобы душа могла ими пользоваться. Как я показываю, древнеегипетские пирамиды и мумии создавались как материальное воплощение сложного культурного сценария, по которому душа фараона, после его смерти шла по пирамиде на небо (ведь он богсолнца), как находящаяся в теле бога и проходящая цикл очищения-возрождения в царстве смерти бога Озириса пребывала в самой пирамиде и в мумии (см. Розин В.М. Философия техники. От египетских пирамид до виртуальных реальностей. М., 2001).

${ }^{48}$ Сравни. «Новая установка в отношении к миру, пишет Зенковский, - тем и определяется, что в сознании ребенка уже с полной ясностью выступает «насамделишный» мир, мир «сам по себе», независимый от фантазии, от творчества ребенка, часто суровый, требующий к себе приспособления. Отсюда рождается интерес к действительности, как она существует сама по себе, выступает позиция того намеренного и планомерного приспособления, которое мы зовем «познанием». Новая установка выводит дитя из прежнего наивного субъективизма - она открывает перед душой ребенка этот необозримый внешний мир - и дитя вступает в свои «годы учения». Оно хочет «знать», хочет проникнуть во все тайны действительности, игра принимает новый характер, нередко становится средством изучения мира, а еще чаще обособляется в особую сферу» (цит. соч. С.66). ву» и при этом ощущает (воображает) себя лошадкой. Принципиальный вопрос: может ли ребенок вообразить себя лошадкой, если он не нащупает, не изобретет все эти процедуры и не начнет их актуально осуществлять? Думаю, что нет, думаю, что и взрослому человеку вообразить себя лошадью практически невозможно, если он не будет имитировать какие-то лошадиные действия. Мало того, ребенок должен не только вспомнить, что делает лошадка, и попробовать делать то же самое, но он никогда не представит себя лошадкой, если не отнесет к себе все эти действия, не начнет жить именно ими, то есть питаться травой, резво скакать по сырой земле, не говорить как человек, а ржать и так далее и тому подобное. Результат этих усилий вполне определенный - ребенок может играть, может общаться с другими уже не только как человек, но и как любимая лошадка.

Не должны ли мы в таком случае предположить, что необходимым условием воображения является, с одной стороны, изобретение действий, создающих особую реальность и предметность (в данном случае «лошадиное поведение»), с другой - усилия, направленные на то, чтобы войти в эту реальность и жить в ней ${ }^{49}$. Правда, зачем ребенку эта реальность? Но разве он не видел сотни изображений лошадей, разве не заразился желанием погладить лошадку и покормить ее, а еще лучше поездить на ней? А какой интересный мир у самой лошади: ее кормят, моют, гладят,

49 Сравни. «Когда, например, дети «играют в родителей», - пишет Зеньковский, - они совершают те движения, которые они замечали у родителей. Внешнее повторение этих движений, сопровождаемое речами, воспроизводящими то, что слышали дети у родителей, как бы ставит детей внешне в позицию родителей. Но входя в свою «роль», совершая ряд движений, дитя невольно следует полету своей фантазии, которая принимает самое живое участие в этой игре. Работа фантазии определена внешне темным эмоциональным вживанием в душу родителей, проективными образами их, но тем свободнее она во внутреннем вживании в «позиции» родителей. Внешние движения неизбежно вызывают игру чувств, дитя переживает новые эмоции, которые определяются игрой фантазии, а не наоборот. Как это возможно, если фантазия, по данному выше толкованию, служит лишь средством выражения чувств? Вопрос этот очень труден, но с ним связана вся тайна расширения наших эмоций, вся тайна «вчувствования» и эмоционального приближения к новым явлениям жизни. Интеллект не только не помогает этому эмоциональному проникновению в новую сферу жизни, но скорее мешает, заполняя сознание своим материалом» (Зенъковский В. Цит. соч. С. 52) 
она возит детей, участвует в забегах и прочее и прочее. У ребенка складывается жгучее желание пообщаться с лошадью и побыть ею. Кроме того, став лошадкой, ты привлекаешь других детей или родителей: они интересуются, как эту лошадку зовут, что она ест и любит и многое другое.

Если обобщить, то получается, что у детской игры несколько функций. Во-первых, она помогает реализовать желания, появившиеся в связи с освоением взрослого мира. Во-вторых, развивает воображение и способствует творчеству. В-третьих, помогает общаться с другими. В-четвертых, это просто очень интересный мир, в котором хотелось бы находиться подольше. Анализ показывает, что детская игра - это еще и схематическая репетиция деятельности, которую возможно придется осуществлять в будущем. Интересные наблюдения по поводу детской игры и у Зенковского.

«Игры, - пишет он, - нужны не только для психо-физического созревания - они не менее (если не более!) нужны для социально-психического созревания...Игры не уводят нас от реальности, они, наоборот, вводят нас в нее, но только смягчают реальность, как бы снимают с нее мертвящую необходимость, в ней царящую. Пластичность объекта игр обладает чрезвычайной, стимулирующей творчество силой: именно она вводит дитя в мир свободы, в мир творчества, она навсегда поселяет в душе сознание своей мощи, своей власти над реальностью. Дитя преображает реальность в игре - и отсюда игра становится психическим лоном, в котором оформляются и развиваются все наши творческие движения (эстетические, этические, религиозные). Но все обаяние игры, все ее очарование покоится на том, что творческая работа все время имеет дело с реальностью. Мы говорили, что для игры обязательна хотя бы самая минимальная доза реальности. Дитя рано научается различать между сферой игры и сферой реальности, между установкой на игру и установкой на деловое отношение. Игра влечет к себе именно тем, что в процессе игры реальное и воображаемое сближаются и сочетаются; этим игра дорога нам и в зрелые годы» ${ }^{\circ}$.

Перейдем теперь к рассмотрению детского мышления и понимания. В названии параграфа мы поставили в кавычки слово «мыслит», чтобы подчеркнуть отличие данной активности от мышления, характерного для взрослого

\footnotetext{
$\overline{50}$ Зенковский В. Цит. соч. С. 55.
}

человека, получающего знания в рассуждениях с использованием понятий и категорий. Ребенок «мыслит» и понимает с помощью схем. Напомним, наше понимание схем. Схема - это семиотическое образование (нарративное или графическое), которое создается (изобретается) индивидом для решения проблем (разрешения проблемной ситуации); схема задает новую реальность, позволяющую понять и по-новому действовать. Исследования показывают, что в первых двух культурах человек осваивал мир именно на основе схем. То же самое можно сказать о ребенке: он осваивает мир и познает его с помощью схем. Одни схемы позволяют ему понять, что происходит, а затем в принципе можно действовать, другие, как действовать при условии понимания. Примеры обоих типов схем мы можем увидеть в уже цитированной книге К.Чуковского. Вот первый тип схем, они ориентированы больше на понимание.

«Поезд налетел на свинью и разрезал ее пополам. Катастрофу увидела пятилетняя дачница Зоря Котинская и пролила много слез. Через несколько дней ей попалась навстречу живая свинья.

- Свинья-то склеилась! - закричала в восторге Зоря» .

Здесь схема - выражение «Свинья-то склеилась», она позволяет понять, почему свинья целая, хотя Зоря видела её разрезанной. Но знание о том, что части сломанного предмета можно склеить эмпирическое, опытное, полученное из наблюдений.

«Мой трехлетний сын впервые познакомился с сосновыми шишками, когда они валялись на земле под деревьями. И лишь через месяца два увидел их на ветках сосны с верхнего этажа нашей дачи:

- Шишки на дерево полезли как-то».

Схема - «шишки на дерево полезли», объясняет, почему шишки оказались на дереве, хотя мальчик видел их на земле. Опять же знание о том, что по дереву можно подняться вверх - опытное.

«Увидала на Невском огромный термометр: - Улица заболела».

Схема : «улица - это больной». Становится понятным, зачем на улице висит термометр; дальше к заболевшей улице можно вызвать и доктора.

Машенька о радио:

- А как же туда дяди и тети с музыкой влезли? И о телефоне:

- Папа, когда я с тобой говорила по телефону, как же ты туда, в трубочку, забрался?» 
Здесь схема такая: в радио и телефоне сидят люди, поэтому голоса и музыка.

«Моя шестилетняя Туська, - пишет мне С.А.Богданович, - увидела беременную и стала смеяться:

- У-у, какой живот!

Я говорю ей:

- Не смейся над тетей: у нее в животе ребеночек.

Туська с ужасом:

- Съела ребенка?!»

Схема - «съела ребенка», вот почему такой живот.

«Рассказ «пятилетнего Волика Шмидта, сына академика Отто Юльевича Шмидта, когда его мать откровенно сообщила ему подлинные и подробные сведения о происхождении детей.

Он тотчас же стал импровизировать длинную повесть о своей жизни в материнской утробе:

“ - Там есть перегородка... между спинкой и животиком.

- Какая перегородка?

- Такая перегородка - с дверкой. А дверка вот такая маленькая. (Смеется.) Да-да. Я сам видел, когда у тебя в животике был. И комнатка там есть малюсенькая, в ней живет дяденька.

- Какой дяденька?

- Я был у него в гостях, пил у него чай. Потом я играл еще в садике. Там и садик есть маленький, и песочек в нем... И колясочка маленькая... Я там с детками играл и катался. А откуда же детки?

- Это у дяденьки породились... Много-много деток. И всё мальчики девочек там нет. И моссельпромовцы сидят... Трое их... Вот такие малюсенькие.

- И ты там жил у них?

- Я приходил к дяденьке в гости, а когда пришла пора родиться, я с ним попрощался за ручку и вышел у тебя из животика». Здесь ребенок выстроил целый небольшой мир на основе разных схем.

Теперь схемы второго типа, объясняющие, что делать в трудных ситуациях.

«Гуляя с теткой по улице, мальчик двух с половиною лет останавливается у книжного киоска.

Продавец спрашивает:

- Умеешь читать?

- Умею.

Мальчику дают книгу:

- Читай.

Он, подражая бабушке, хватается внезапно за карман:
- Я забыл дома очки».

В данном случае схема: «Я забыл дома очки». И не стоит думать, что ребенок врет, он создает реальность, позволяющую уклониться от чтения.

«- Папа, да сруби ты, пожалуйста, эту сосну... Она делает ветер; а если ты срубишь ее, станет тихо и я пойду гулять».

Схема типичная, в том числе для аборигенов: «деревья делают ветер». С одной стороны, она объясняет, почему деревья качаются (они машут верхушками, погоняя ветер), с другой - понятно, что делать: надо остановить деревья.

«У Славы в папиросной коробке пчела. - Зачем ты мучаешь пчелу? Выпусти ее.

- Как же! "Выпусти”! Я ее доить буду! Она мне будет мед давать!

Здесь следующая схема: «пчелы дают мед, корова - молоко, пчела это маленькая корова».

«Леночка Люляева попросила у бабушки китайский сервиз.

- Когда будешь выходить замуж - подарю.

Леночка сейчас же к отцу:

- Папочка, дорогой, давай с тобой поженимся, и тогда у нас будет китайский сервиз».

Схема понятная: «папа - это потенциальный муж, а Леночка - жена».

Чуковский объясняет эти замечательные детские высказывания и рассуждения таким образом, что - это детская фантазия, обусловленная слабыми знаниями. То есть его объяснение основывается на отождествлении детского и взрослого интеллекта. Но если не делать такого отождествления, то нужно утверждать другое: дети выстраивают дискурс, опирающийся и на имеющиеся у них опытные знания и главным образом на схемы, которые они тут же изобретают. Именно схемы задают реальность, позволяющую понять и что-то делать. При этом нетрудно заметить, что в детском дискурсе сходятся верные знания, полученные ребенком из опыта или от взрослых, и знания, которые он получает на схемах. Схема же строится таким образом, что бы стало понятно и ребенок смог себя реализовать. Схема может быть удачной, работающей и неудачной, не работающей. Вот пример последней.

Вспоминаю сон, приснившийся во время войны под Куйбышевым, когда мне было лет пять-шесть. Моя мама день и ночь работала на авиационном заводе и лишь изредка урывала несколько часов в месяц, чтобы навестить меня и брата в детском саду. Но почти всегда она приносила что-то вкусное - какао в термосе, 
или шоколад или что-нибудь еще. И вот мне упорно начал сниться сон с мамой и вкусными вещами в придачу. Понятно, как я огорчался, когда просыпался: нет ни мамы, ни какао. Наконец, чтобы не обманываться и не огорчаться понапрасну, я решил проверять себя: щипать за ухо, если больно - не сплю, если не больно - сплю. И в ту же ночь мне приснился очередной сон. Приезжает мама, я дергаю себя за ухо, убеждаюсь, что не сплю, пью какао и затем... просыпаюсь. Дальше все ясно. Сила огорчения прочно отпечатала этот сон в моей памяти. Запомнил я примерно и то, как рассуждал.

Так как после сна никого и ничего не было, решил я, то значит «во сне нет ни мамы, ни шоколада, ни меня». А следовательно «я не почувствую боли, если буду дергать себя за ухо», в отличие от того, как чувствую боль, когда не сплю. Вот какие две схемы я построил, но они оказались неправильными, не позволили мне различить сон и реальность (сновидение и бодрствование) ${ }^{51}$. В то же время понятно, что построенные схемы были рассчитаны на то, чтобы реализовать себя (чтобы зря не огорчаться). Создавая их, я использовать и правильное эмпирическое знание, что «после сна нет того, что приснилось». В этом смысле детский дискурс, как правило, гетерогенный, т.е. состоит из правильных и неправильных (с точки зрения взрослых, но не ребенка) знаний.

Наконец, еще один интересный случай, описанный Н.Бердяевым в своей автобиографии: «Акимушка, - пишет он, - рассказал мне однажды о необыкновенном событии, происшедшем с ним, когда он был мальчиком. Он был пастухом и пас стадо. И вдруг у него явилась мысль, что Бога нет. Тогда солнце начало меркнуть, и он погрузился в тьму. Он почувствовал, что если Бога нет, то и ничего нет, есть лишь совершенное ничто и тьма. Он как будто бы совершенно ослеп. Потом в глубине ничто и тымы вдруг начал загораться свет, он вновь поверил, что есть Бог, “ничто” превратилось в мир, ярко освещенный солнцем, все восстановилось в новом свете» ${ }^{2}$.

\footnotetext{
${ }^{51}$ Значительно позднее, уже взрослый, понял, что могу присутствовать во сне, но только это мое я, которое снится, «сновидческое», необычное, оно может делать то, чего я не могу, например, во сне я могу летать (и много раз летал). Кроме того, я понял, что, находясь во сне, я не могу удостовериться, что не сплю и всего лишь вижу сон. Во сне я уверен, что живу какой-то жизнью, а не сплю. Подобно тому, как моя дочь открыла «рисуночное» солнце, я открыл свою «сновидческую» личность. $5^{2}$ Бердяев Н. Самопознание (опыт философской автобиографии). М. 1990. С. 189.
}

Вначале фантазия Акимушки, артикулированная в предложении «Бога нет» (очевидно, это была схема, которую он выстроил, разрешая какую-то проблему) породила реальность, в которой, однако, не было места ни солнцу, ни жизни самого мальчика. Потом Акимушка, спасая себя (разрешая катастрофическую проблемную ситуацию), построил схему «Бог есть», позволившую восстановить мир. Но, рассказывая этот случай Бердяеву, Акимушка поставил телегу впереди лошади: он думал, что сначала загорелся свет, а потом он поверил, что Бог есть. Хотя, с нашей точки зрения, именно схема задала реальность, в которой можно было жить. Когда я пишу, что схемы задают реальность, речь идет вовсе не об условной, виртуальной реальности, а о подлинной, настоящей, определяющей жизнь человека.

\section{Завершение детства}

Прежде всего обсудим, почему детство воспроизводится и существует относительно долго. Здесь два основных фактора: внешний и внутренний. С одной стороны, как уже отмечалось, именно взрослые и педагоги организовали детство, признав за детьми внутренний мир, своеобразие, закономерности развития. Плюс феномен прамы, который тоже создает для детей достаточно жесткие условия жизни и развития. Взрослые поддерживают эту организацию и условия до тех пор, пока не считают, что пришло время для самостоятельной жизни ${ }^{53}$. Как правило, это время совпадает с началом учебы в школе, где от детей начинают требовать самостоятельное поведение. В результате складываются новые условия для становления личности. Именно начало становления личности знаменует собой завершение детства.

С другой стороны, жизнь и развитие ребенка в рамках заданных взрослыми организации и условий способствует вполне определенным особенностям детского бытия (опора

\footnotetext{
53 «Социальная специфика ребенка заключается в том, что он изначально выступает как представитель одновременно двух больших социальных общностей мира взрослых и мира детей - и в этом смысле он маргинал. "Ребенок по своей природе всегда оказывается неполноценным в обществе взрослых; его позиция с самого начала дает повод для развития у него чувств слабости, неуверенности и затрудненности”» (Абраменкова В.В. Современная общая образовательная ситуация изучения ребенка и предмет социальной психологии детства М., 2003; Артемъева Е.Ю. Психология субъективной семантики. М., 1980).
} 
на взрослого, означение действительности, мышление схемами, освоение мира взрослых с помощью игры и других семиотик). Эти особенности характерны для всего периода детства. Однако жизнедеятельность ребенка в течение всего детства постоянно усложняется (сначала он осваивает значения слов, потом - взаимоотношения с людьми - взрослыми и детьми - затем учится создавать схемы и играть, расширяет зону свободы и одновременно схватывает основные «правила игры», которым подчиняется жизнь, и т.д.). Переходя к самостоятельному поведению, ребенок быстро убеждается, что навыки и способности, выработанные в период детства, уже не работают, что нужно перестраиваться. Другими словами, детство уходит.

Завершение детства - это период становления личности, когда подросток впервые совершает настоящие самостоятельные поступки. Поступки разные, не всегда понятные, с точки зрения дальнейшего нашего развития. Начну с себя.

Прекрасно помню, как прорезалась моя личность, если только, конечно, это была личность. Было 1-е сентября, после летних каникул. Я пришел в четвертый класс и как будто проснулся. Именно с этого времени я себя воспринимал, к себе присматривался, наблюдал за собой. Ощущение личности было столь необычным, что я хорошо запомнил свое состояние и переживания. Мне казалось, что все, что было до этого, уходит в сплошную темноту. Лишь отдельные картины были разбросаны в этом темном прошлом.

Совсем другое начинается с четвертого класса. Я именно открываю себя, мне кажется, что теперь помню себя непрерывно, хотя это, конечно, что понял позднее, было иллюзией. Продумывая, почему это произошло, нашел причину, с одной стороны, в чтении книг, именно к этому времени я начал достаточно уверенно и много читать, с другой - в том, что пошел в школу, да и дома был все время один (отец находился в армии, а мама пропадала на работе). Книги дали форму осознания себя, а самостоятельная жизнь в школе и дома заставили перестроиться. Я уже не мог, как прежде рассчитывать на помощь мамы или воспитателя, пришлось опереться на самого себя. Книги подсказали, как это сделать - взглянуть на себя со стороны, увидеть себя, охарактеризовать свое $Я$.

Вообще к этому времени (пятый - шестой класс) я полностью жил в книгах. Художе- ственные события интересовали меня значительно больше, чем окружающая бедная послевоенная жизнь. В те годы никаких телевизоров и плееров еще не было, игрушек практически тоже. Мы жили в огромном доме фабрики «Шерсть-сукно» с коридорной системой. В одном конце коридора находилась общественная кухня, где однажды я в течение двух минут наблюдал фантастический танец жирных крыс, в другом конце коридора располагались два общих туалета.

В доме было всего две еврейских семьи. Антисемитизм процветал как среди взрослых, так и их детей. Мне с братом не раз приходилось отстаивать свою независимость с помощью кулаков, помню, например, как мы стояли во дворе в окружении дружно плюющих в нас сверстников. Все это тоже не стимулировало желание жить обычными событиями, как только выдавался случай, я старался нырнуть в мир книг, где гуляли благородные дамы, джентльмены и злодеи, кипели страсти, мучались и размышляли о жизни герои. Когда случай не выдавался, я пытался его создать сам, читал даже ночью под одеялом, включая фонарик, и осторожно, чтобы не разбудить маму, переворачивал страницы.

Естественно, что при таком образе жизни уроки я готовить не успевал. Каждый день со страхом ждал, не вызовет ли учитель. Но рано или поздно моя фамилия произносилась. В результате я так запустил учебу, что уже боялся идти в школу. Где-то недели две или больше я вместо школы шел в метро. Спрашивается, это был поступок или нет? Я находил за станцией «Электрозаводская» в урнах несколько плохо оторванных билетов, и, зажав пальцами оборванный край, проходил мимо контроля. В метро находил свободную скамейку и сидел на ней, глотая очередную книгу. В положенное время, как ни в чем не бывало, я возвращался домой. Так бы и продолжалось неизвестно сколько времени, если бы кто-то из класса не увидел меня в метро и не сказал об этом классному руководителю. Я во всем повинился, обещал нагнать учебу и только просил, чтобы не рассказывали матери. Она узнала об этой истории буквально несколько лет тому назад от меня самого.

Примерно в это время я прочел «Обломова» и был потрясен. Почему-то решил, что я - точная копия Илья Ильича, в частности, так же безволен, как последний, поскольку не могу ради книги сесть за уроки или прибрать в комнате. По-настоящему испугался, гени- 
ально обрисованная Гончаровым перспектива зарастания коростой и гибели живой души ясно предстали передо мною. Я решил спасать себя, воспитывать свою волю. Начал он с простого задания - старался не говорить ни слова в течение двух дней. Следующее задание было сложнее, потом еще сложнее. Так я вступил на тропу войны с самим собой. Здесь уже, без сомнения, был поступок. На этом пути терпел больше неудач, чем побед, но все же не прекращал сражения много лет. Постепенно мои усилия, к удивлению, стали приносить плоды, и к девятому классу я стал уже вполне организованным молодым человеком. К этому времени семья переехала в город Анапу, что тоже способствовало оздоровлению моей личности.

Глядя назад издалека, я думаю, что, как ни странно, большую роль в формировании его личности сыграла не только литература XIX, XX веков, которую с любовью собирали мать и отец, но и общая неустроенность тогдашней жизни, обусловившая то обстоятельство, что я жил как бы без родителей. Я или должен был пропасть, как это произошло со многими сверстниками, или стать личностью, способной к самостоятельному поведению и осмыслению действительности. Почему-то произошло последнее.

Теперь второй кейс - история, приключившаяся с юным Карлом Юнгом. Обратимся к одному подростковому воспоминанию и переживанию Юнга. Содержание этого переживания таково. Однажды в прекрасный летний день 1887 года восхищенный мирозданием Юнг, подумал:

«Мир прекрасен и церковь прекрасна, и Бог, который создал все это, сидит далеко-далеко в голубом небе на золотом троне и ... Здесь мысли мои оборвались и я почувствовал удушье. Я оцепенел и помнил только одно: Сейчас не думать! Наступает что-то ужасное» ${ }^{4}$.

После трех тяжелых от внутренней борьбы и переживаний дней и бессонных ночей Юнг все же позволил себе додумать начатую и такую, казалось бы, безобидную мысль.

«Я собрал, - пишет он, - всю свою храбрость, как если бы вдруг решился немедленно прыгнуть в адское пламя, и дал мысли возможность появиться. Я увидел перед собой кафедральный собор, голубое небо. Бог сидит на своем золотом троне, высоко над миром - и из под трона кусок кала падает на сверкающую новую крышу собора, пробивает ее, все рушиться, стены собора разламываются на куски.

${ }_{54}$ Юнг К. Воспоминания, сновидения, размышления. Киев, 1994. С. 46.
Вот оно что! Я почувствовал несказанное облегчение. Вместо ожидаемого проклятия благодать снизошла на меня, а с нею невыразимое блаженство, которого я никогда не знал... Я понял многое, чего не понимал раньше, я понял то, чего так и не понял мой отец, - волю Бога... Отец принял библейские заповеди как путеводитель, он верил в Бога, как предписывала Библия и как его учил его отец. Но он не знал живого Бога, который стоит, свободный и всемогущий, стоит над Библией и над Церквью, который призывает людей стать столь же свободным. Бог, ради исполнения Своей Воли, может заставить отца оставить все его взгляды и убеждения. Испытывая человеческую храбрость, Бог заставляет отказываться от традиций, сколь бы священными они ни были» 55 .

Перед нами сложная схема, на которую Юнг выходил трое суток. Она задает новое понимание Бога и установку на практическое действие - разрыв с Творцом и отцом. Но рассмотрим подробнее. Первый вопрос, который здесь возникает, почему подобное толкование мыслей является следованием воли Бога, а не, наоборот, ересью и отрицанием Бога? Ведь Юнг договорился до того, что Бог заставил его отрицать и церковь и сами священные религиозные традиции. Второй вопрос, может быть даже еще более важный, а почему собственно Юнг дает подобную интерпретацию своим мыслям? Материал воспоминаний вполне позволяет ответить на оба вопроса.

В тот период юного Юнга занимали две проблемы. Первая. Взаимоотношения с отцом, потомственным священнослужителем. По мнению Юнга отец догматически выполнял свой долг: имея религиозные сомнения, он не пытался их разрешить, и вообще был несвободен в отношении христианской Веры и Бога. Вторая проблема - выстраивание собственных отношений с Богом, уяснение отношения к Церкви. Чуть позднее рассматриваемого эпизода эти проблемы были разрешены Юнгом кардинально: он разрывает в духовном отношении и с отцом, и с Церквью. После первого причастия Юнг приходит к решению, которое он осознает так.

«В этой религии я больше не находил Бога. Я знал, что больше никогда не смогу принимать участие в этой церемонии. Церковь - это такое место, куда я больше не пойду. Там все мертво, там нет жизни. Меня охватила жалость к отцу. Я осознал весь трагизм

\footnotetext{
55 Там же. Стр. 50.
} 
его профессии и жизни. Он боролся со смертью, существование, которой не мог признать. Между ним и мной открылась пропасть, она была безгранична, и я не видел возможность когда-либо преодолеть ее» ${ }^{56}$.

Вот, оказывается, в каком направлении эволюционировал Юнг. На этом пути ему нужна была поддержка, и смысловая и персональная. Но кто Юнга мог поддержать, когда он разрывает и с отцом, и с Церквью? Единственная опора для Юнга - он сам, или, как он позднее говорил, «его демон»57. Однако понимает этот процесс Юнг иначе: как уяснение истинного желания и наставления Бога. Именно подобное осознание происходящего и обуславливают особенности понимания и интерпретации Юнгом своих мыслей. Юнг, самостоятельно делая очередной шаг в своем духовном развитии, осмысляет его как указание извне, от Бога (в дальнейшем во взрослой профессиональной жизни как указание от бессознательного, от архетипов), хотя фактически он всего лишь оправдывает и обосновывает этот свой шаг. На правильность подобного понимания указывает и юнгеанская трактовка Бога. Бог для Юнга - это его собственная свобода, а позднее, его любимая онтология (теория) - бессознательное. Это пример позволяет понять также еще одну вещь - роль ранних форм социализации. Почему, спрашивается, Юнг придает такое значение своим фантазиям, верит им? Не потому ли, что в противоположном уже не мог разубедить его отец, ведь Юнг находился с ним в конфликте. Поэтому Юнг с удовольствием подчиняется требованиям Бога, повелевающему стать свободным, следовать своему демону, отдаться бессознательному.

Итак, приходиться признать, что Юнг приписал Богу то, что ему самому было нужно. Интерпретация мыслей Юнга, также как затем и других проявлений бессознательного

\footnotetext{
${ }_{56}$ Там же. Стр. 64.

57 «Но существовал и другой мир, и он был как храм, где каждый забывал себя, с удивлением и восторгом постигая совершенство Божьего творения. В этом мире жил мой «Другой», который знал Бога в себе, он знал его как тайну, хотя это была не только его тайна... «Другой», «номер 2» - типичная фигура, но осознается она немногими... мир моего второго «Я» был моим, и все же у меня всегда оставалось чувство, что в том втором мире было замешано что-то помимо меня. Будто дуновение огромных миров и бесконечных пространств коснулось меня, будто невидимый дух влетал в мою комнату - дух кого-то, кого давно нет, но кто будет всегда, кто существует вне времени» (там же, Стр. 55, 74).
}

- сновидений, фантазий, мистических видений представляет собой своеобразную превращенную форму самосознания личности Юнга. Превращенную потому, что понимается она неадекватно: не как самообоснование очередных шагов духовной эволюции Юнга, а как воздействие на Юнга сторонних сил - Бога, бессознательного, архетипов.

Третий кейс - реальная жизненная история, пересказанная в третьем номере газеты «Еврейское слово» Аркадием Красильщиковым.

«Из колхозу мне удалось сбечь в четырнадцать годков, - начала свой рассказ Клавдия Зотова. - Нужны были работницы на торфоразработках. В деревню нашу прислали ответственного товарища, он меня и внес без лишнего разговора в списки, не поглядев, что годков мне мало. Я росту была большого и сильная на вид.

Два года потом жила в бараке и работала формовщицей на прессе по 12-14 часов в сутки, но к пятьдесят первому году предприятие это свернули за нерентабельностью, в бараках стали селить бывших зеков, высланных на 101-й километр. Я же должна была вернуться в колхоз - с голодухи пухнуть, но тут нашелся добрый человек и устроил меня на ткацкую фабрику в город Порхов...

Теперь скажу о главном. Работал у нас на фабрике один еврей семейный по фамилии Лонж, Яков Самойлович. Фельдшером работал в здравпункте. Был женат, имел двоих детей, с большой разницей в возрасте. Старшему сыну Вене, как мы познакомились, было уже 17 лет, а младшенький - Сашок - только народился.

У меня случилась большая любовь к этому Вене. Можно сказать, я из-за этой любви и поступила в вечернюю школу учиться, в пятый класс, а он, Венечка, как раз десятый кончал в школе обычной. Вене может поначалу тоже показалось, что мила я ему и желанна. Я у него первой женщиной стала в жизни. Наша любовь с год продолжалась, а потом его в армию забрали, и он мне оттуда письмо отписал, что просит прощения за все, но больше близость со мной соблюдать не намерен, не хочет меня обманывать и предлагает не ждать его с Дальнего Востока, а устроить свою личную жизнь с другим человеком.

Много времени прошло, но могу смело сказать, что горя сильнее не было в моей жизни. Хотела даже руки на себя наложить.

Нужно вспомнить, какое было время тогда. Все вокруг говорили, что евреев скоро высылать будут на Север, в лагеря, так как они 
«убийцы в белых халатах». Отца Вени с медицинской работы выгнали, но директор наш был человек добрый и умный. Он Якова Самойловича оставил при фабрике разнорабочим. Так и сказал: «до лучших времен»

Мне доброты и ума не хватило. Я страшным письмом Вене ответила. Смысл письма был такой: как он, жидовская морда, посмел меня, русскую девушку, бросить, надсмеялся над моими высокими чувствами.

Веня на это письмо не ответил, а я все горела страшным огнем. Я вдруг возненавидела не только его, но и все семейство Лонжей. Я тогда задумала страшную месть: решила украсть их недавно рожденного сыночка, отнести его в дальний лес и там бросить в снег, чтобы он умер холодной смертью. Я тогда подумала, что мне за это ничего не будет от властей, потому что все евреи в СССР будто стали вне закона, и с ними можно было делать все что угодно.

Надо сказать, что наше общежитие было близко от дома Венички моего. Вот однажды и случился подходящий момент младенца выкрасть. Маленький меня хорошо знал и улыбался, когда я его в коробку большую из фанеры посадила. Так и несла до леса. Он мне оттуда агукал из коробки, а потом даже заснул. Так я почти бежала с Сашком более часа, а потом ушла от дороги по глубокому снегу в лес, поставила коробку под ель и стала бечь от этого места.

Тут Сашок будто понял все и заплакал. Он плачет в крик, а я бегу. Потом как-то вдруг силы кончились, упала, хватаю снег губами и ясно понимаю, что не смогу бросить маленького так, на смерть.

Вернулась, взяла его на руки, а Сашок сразу плакать перестал. У него всю жизнь был такой характер. К людям с большим доверием относился. Никогда потом не верил, что человек человеку волк, даже во взрослом возрасте не верил».

Клавдия решила выдать украденного мальчика за своего сына, прижитого от случайного человека, отвезла в деревню к матери, которая сначала его и воспитывала. Потом Зотова взяла заболевшую мать с «сыном» к себе. Судьба Саши сложилась удачно: он окончил школу с отличием, поступил на математический факультет МГУ, закончил аспирантуру и затем стал работать в «почтовом ящике».

«И тут я заболела. Тяжело заболела раковым заболеванием груди. Случайно подслушала разговор врачей о своей судьбе, что жить мне осталось совсем недолго. Тут меня совесть стала мучить, и вызвала я Сашко прямо к операции своей. Он прилетел сразу же.
Сел у моей кровати в этой чертовой районной больничке, смотрит на меня и говорит всякие слова, руки мне целует. Вот оно отговорился, тогда и моя очередь пришла говорить.

Он все узнал из моего больного шепота. И про ту коробку из фанерки зимой, и про своих родителей, и про мою любовь к его брату Веничке. Шепчу и плачу, шепчу и плачу. Глаза закрыла, боюсь на Сашку смотреть. Потом открыла глаза: смотрю - по его щеке тоже слеза бежит.

- Жалко мне тебя, мама, - говорит мой сынок украденный. - Так жалко, что и сказать тебе не могу.

Надо же, такие слова мне...Что дальше? Как видите не померла я. Живу, вот уже 13 лет после того смертного приговора. А Сашка мой нашел отца, совсем старенького, и брата (мама его к тому времени померла). Он их нашел, выправил свои документы по новой, а в 1993 году подались они всей семьей в Израиль...

Семья у Вени хорошая, детей трое, уже внуки имеются. Я с ним два раза виделась. Один раз в России, другой - здесь, недавно. Все прощения просила, но он вздыхал тяжко, ничего не сказал. Думаю, не простил меня из-за матери. Та всю жизнь Сашеньку своего вспоминала...» ${ }^{58}$.

Назовем все своими словами, безусловно, Клавдия Зотова совершила преступление (украла ребенка) и многие годы не раскаивалась в этом. Ею двигали желание мести и «голые схемы»- распространенные в те годы культурные сценарии, что евреи - «убийцы в белых халатах» и «ей за это ничего не будет от властей, потому что все евреи в СССР будто стали вне закона, и с ними можно было делать все что угодно» ${ }^{59}$. В период преступления она

\footnotetext{
24-30 января 2007. ры. Вспомним Александра Сергеевича
}

${ }^{58}$ Красильщиков А. Еврейская месть. Быль. ЕС. N 3.

${ }^{59}$ Интересно, что даже сюжет мести (отнести в лес на холодную и голодную смерть) взят из культу- 
явно была не в себе («я все горела страшным огнем»). С одной стороны, Клавдия всю жизнь любила Веничку, а с другой - ввергла в трагедию его семью и ускорила смерть его матери.

Но убить ребенка Клавдия все же не смогла, хотя хотела. Более того, она его полюбила, воспитала как своего, а на пороге смерти ее «стала мучить совесть», она два раза выпрашивала прощения у своего Венички. Зотова все же имеет совесть, она не может убить маленького ребенка, заботится о нем и любит его. У Клавдии была добрая и любящая мать, и сама Зотова способна на большую любовь (правда, как говорят в народе, любила «по-своему»). Но главное, оказалось, что для Клавдии маленький ребенок - это не орудие мести, а беззащитное дитя, нуждающееся в защите и любви. Немаловажными являются и угрызения совести ${ }^{60}$.

Продумаем эти три кейса. Во всех случаях речь идет о становлении личности в юном возрасте и поступках, во многом определивших жизнь человека. Я начал работать над собой и продолжаю это делать до сих пор. Юнг, порвав с отцом и церквью и приписав Богу нужные качества, и дальше в науке и жизни следовал этому образцу. Клавдия Зотова, украв ребенка, определила тем самым всю свою дальнейшую жизнь. Обсуждая, что такое личность, Александр Асмолов ссылается на Леонтьева:

«А.Н.Леонтьев писал: “Первые активные и сознательные поступки - вот начало личноcти. Становление ее происходит в напряженной внутренней работе, когда человек как бы постоянно решает задачу, “чему во мне быть”... Чем больше действие человека отклоняется от типичных действий большинства людей, тем вернее, что за ним стоят "внутренние" личностные факторы - внутренние “диспозиции” (предрасположенности к действиям)» ${ }^{61}$.

Во всех случаях наши герои действовали самостоятельно, что является одним из признаков становления личности. При этом они вышли на новое понимание реальности, построив соответствующие схемы (им потребовалась такая опора). Автор увидел свою судьбу в образе Обломова. Юнг узнал «волю Бога, стоящего над Библией и Церквью, заставляющего отказываться от традиций, сколь бы

\footnotetext{
6о Недавно появившийся на экране фильм «Остров» поразил современную зрительскую аудиторию именно тем, что главный герой фильма всю жизнь переживает угрызения совести и старается помощью людям, чтобы искупить свой грех.

${ }^{61}$ Асмолов А. Г. Психология личности. Принципы общепсихологического анализа. М., 2001. С. 140.
}

священными они ни были». Клавдия Зотова убедила себя, что «евреи в СССР вне закона, и с ними можно делать все что угодно».

Итак, становление личности, поступок, новая реальность, вошедшая в сознание. Асмолов объясняет становление личности очень просто: личность исходно существует в человеке, но до поры до времени спит. Противоречия в деятельности человека пробуждают ее.

«Поиск “двигателя”, дающего начало активности личности, необходимо искать в тех рождающихся в процессе потока деятельностей противоречиях, которые и являются движущей силой развития личности”... Выступая как источник развития личности социально-исторический образ жизни как бы задает появившемуся на свет человеку сценарий, втягивая его в определенный распорядок действий. Жесткость этого распорядка действий зависит прежде всего от того, насколько варьирует в конкретном социальноисторическом образе жизни свобода выбора тех или иных видов деятельности» ${ }^{62}$.

В предложенной Асмоловым схеме человек "выбирает" виды деятельности, “овладевает" собственным поведением, решает задачу “чему в нем быть” и т. п., то есть он уже сознателен и сформирован, но его личность была на заднем плане и до поры до времени не осознавалась. Однако, что тогда объясняется, ведь главное как раз понять, откуда эта личность взялась и как она сформировалась?

Подобный подход, когда вводится предпосылка о предсуществовании личности, которая затем, в процессе развития себя раскрывает (то есть полагание своеобразного гомункулуса), объясняет и важный тезис А.Асмолова о том, что личность в истории была всегда.

«Итак, - пишет он, - на самых разных этапах человеческой истории в развитии культуры ведут между собой нескончаемый диалог социотипическое и индивидуальное поведение личности. Наличие этого диалога служит доказательством того, что в истории не было безличного периода существования общества» ${ }^{63}$.

Не подтверждает ли история с Юнгом концепцию Александра Асмолова? Разве не он сам решает «чему в нем быть». Кто в нем это решает, если не его личность? Кто решал для автора, что он будет себя переделывать и закалять свою волю? Однако не все так просто.

\footnotetext{
62 Там же. Стр. 195, 340.

63 Там же. Стр. 310.
} 
Ведь на Юнга решительное влияние оказало его желание порвать с отцом и церквью, а на меня влияние гуманистической литературы и слезы моей матери. Может быть, поступок и новая реальность только оправдывали это давление? К тому же, как уже отмечалось, современные культурологические и историкопсихологические исследования показывают, что личность довольно позднее образование. В филогенезе она складывается не раньше античной культуры, а в онтогенезе только в подростковом возрасте, когда взрослые, посылая ребенка в школу, начинают склонять его к самостоятельному поведению.

Обратим внимание еще на два момента. Первый, поведение Юнга близко к асоциальному, а Клавдии Зотовой вполне асоциальное, даже криминальное. В воспоминаниях Юнга есть, в частности, такой выразительный пассаж.

«Ребенком я чувствовал себя одиноко, и я одинок до сих пор, поскольку я знаю, и я должен объяснить и напоминать людям то, что они не знают и, в большинстве случаев, не хотят знать... С некоторыми людьми я был очень близок, по крайней мере до тех пор, пока они были как-то связаны с моим внутренним миром; но затем могло случиться так, что я вдруг отстранялся, потому что не оставалось ничего, что могло меня с ними связывать. До меня с трудом доходило, что люди продолжают существовать - даже когда им уже нечего сказать мне... Я мог увлекаться многими людьми, но стоило мне проникнуть в их суть, волшебство исчезало. И я нажил себе множество врагов. Но всякий человек, если он человек творческий, не принадлежит себе. Он не свободен. Он - пленник, влекомый демоном» ${ }^{64}$.

В этом исповедальном тексте нетрудно узнать традицию Сократа, доведенную до предела, до крайности романтической эпохой мысли: подобно великому греку, Юнг говорит обществу и толпе крайне неприятные вещи и одновременно понимает, как чудовищно он сам выглядит в свете обыденной общественной морали.

Тем не менее, Юнг вполне здоровый в психическом отношении человек. А вот Клавдия Зотова, здорова ли она? Юрист и психиатр скажет, что, конечно же, да. Юрист еще добавит, что Зотова - преступница. И оба они вынуждены будут признать, что сегодня тысячи, если не миллионы и миллионы людей похожи в своих поступках на Клавдию Зотову. С одной

\footnotetext{
${ }^{64}$ Юнг. Цит. соч. Стр. 351.
}

стороны, они вроде бы не безумны, и в обычной жизни мало чем отличаются от остальных людей, с другой - преступники (насильники, убийцы и прочее). Если они нормальные люди, то, как могли совершить такие преступления (украсть ребенка, убить, изнасиловать)? Уже два раза по ТВ был показан страшный сюжет. Вполне нормальный по обычным меркам человек, «хороший производственник и товарищ» (будем так его дальше и называть), выкопал на своем огороде глубокий погреб, замаскировал и оборудовал его по последнему слову техники, затем поймал двух девушек и много лет держал в своей тюрьме и насиловал. При этом с точки зрения психиатров, он вполне вменяем, понимал, что делает, может отвечать за свои поступки перед судом.

\section{Проблема нравственного воспитание детей в ситуации перехода и кризиса культуры}

Современные российские родители - продукты воспитания, характерного для XX столетия, по поводу которого Зеньковский так тревожился, обращая внимание на его идеологичность и бездуховность. В то же время именно в правильном воспитании Зеньковский видел выход из положения, сложившегося в 20-х годах прошлого столетия. «Взгляните на то, - пишет он, - что делается даже теперь во всех уголках России: вы найдете всюду некоторое число активных, одушевленных общественными идеалами деятелей, которые переобременены работой, надрываются от массы дела, на них возложенного. А за ними стоит целая масса «обывателей», которые умеют только пользоваться результатами чужой работы, пожалуй, не прочь критиковать ее, но палец о палец не ударят, чтобы помочь. Слабое развитие общественной самодеятельности тем более поразительно у нас, что жизнь сейчас стала невыносимо тяжкой. Продовольственный, квартирный, финансовый кризисы давят всех нас, и несмотря на все это все же на арене общественной работы выступают одни и те же лица. Этот факт следует признать грозным, он таит в себе большую опасность для нашего общества, для всего народа. Завоеванная политическая свобода, широкая демократизация жизни не приведут к обновлению России, к расцвету ее, если общественная самодеятельность будет стоять на том же уровне, на каком стоит она ныне. Я не говорю уже о тех позорных фактах, которых 
оказалась такая масса, - о той нечестности, небрежности, преступном попустительстве, равнодушии к интересам общества, какие обнаруживают многие деятели нашего времени. Эти пороки, отравляющие весь наш народный организм, растут тем сильнее, чем меньше у нас сознания своего общественного долга, чем меньше у нас духа солидарности. <...>

У нас в России, при прежних условиях общественной жизни, когда сурово преследовалось всякое искреннее и честное служение общественному благу, естественно выдвигался самой жизнью и исторически закреплялся тип социально равнодушного и социально инертного человека. К этим чисто русским условиям, благоприятствовавшим всем нашим Обломовым, надо присоединить и тот фактор, который оказывает свое действие всюду, именно влияние экономического индивидуализма нашей эпохи. Экономическая структура нашего времени раздвигает людей, заставляет каждого думать о себе, ведет к культу своих интересов. Самый прогресс экономический во многом основывается на эгоистическом служении личному интересу. В силу этого экономического фактора как-то слабеют, отодвигаются вглубь естественные социальные влечения, гаснет интерес к социальному целому. Было бы наивно не учитывать этот фактор в вопросе о причинах распространенности социально инертного типа. <...>

Было бы правильнее говорить, что современная школа воспитывает не антисоциальные навыки, но что она воспитывает дурную социальность. Соревнование, зависть, тщеславие и т. п., это тоже социальные чувства, имеющие свой корень, свой смысл лишь в социальной среде, - но эти чувства не сближают, а раздвигают людей. <...>

Не входя здесь в подробное обсуждение вопроса о социальной борьбе, следует сказать, что нет никаких серьезных оснований слишком заострять социальные противоречия различных классов...Люди, принадлежащие к различным социальным классам, никогда не перестанут быть друг для друга, прежде всего, людъми! В социальном воспитании мы должны подготавливать детей именно к такому социальному общению, в котором основное место принадлежало бы чисто человеческим, а не классовым отношениям. <...>

Я хотел бы в связи с указанным отметить еще и то, что современная школа грешит вообще односторонним интеллектуализмом, т. е. как-то искусственно развивает ум, совер- шенно однако не развивая общей активности и даже подавляя проявления ее. В этом лежит разгадка одного из наиболее грустных «парадоксов» современной школы: сосредоточивая все свои силы на развитии ума, она не только не добивается своих целей, не только не дисциплинирует ума и не развивает его, но часто даже притупляет и приостанавливает его естественное развитие. <...>

К сожалению, современная семья переживает глубокий кризис, обусловленный целым рядом причин. Рост индивидуальности, ведущий к повышенным запросам личности, часто не находит себе удовлетворения в семье; муж и жена часто образуют семью лишь внешне, а духовно остаются чуждыми друг другу. В семье нет эмоционального единства, нет эмоциональной близости, - т. е. нет почвы для настоящего социального общения. Семья превращается в сожительство, в физическое соседство. Люди ведут одинаковую, а не одну жизнь, пульс семейственности, внутренней теплоты и близости почти совершенно не слышится. Большей частью в современных семьях чувствуется глубокий надлом, трагическое расхождение, в силу чего сожительство становится часто мучительным. Почва для ссор, взаимного непонимания, для взаимных обвинений всегда готова, от всякого пустяка может загореться настоящая сцена. Взаимных обид становится больше, чем услуг, горечи больше, чем радости. Друг другу надоедают, тяготятся обществом другого, при первом удобном случае уходят к другим, легко увлекаются кем-нибудь на стороне, а то и просто бросают семью. Развал семьи спускается все ниже и ниже в здоровые слои народа и грозит стать всенародным бедствием. <...>

O, как не хватает сейчас России элементарных социальных добродетелей! Как мало людей, умеющих подчинить свои личные, партийные, классовые интересы общему благу! Богатая страна, полная молодых, неиспользованных сил, освобожденная от всех внешних пут, имеющая полную возможность свободного самоопределения, смутно сознающая всю свою бесконечную силу, - Россия со дня на день приближается к катастрофе, раздираемая изнутри социально противоречивыми течениями. Пусть же спасут родители и школа детей от страшного растления, которое несет с собой отравленная жизнь и пусть подготовят они в детях любовь к общему благу, способность к социальному сближению, основные социальные добродетели, 
живое стремление к солидарности, подлинную, а не словесную только любовь к братству! Пусть в противовес всем страшным фактам взаимного озлобления, взаимного недоверия и ненависти пробуждают они в детских душах живую любовь к человеку, как таковому, социальную отзывчивость, сознание гражданского долга, честное исполнение взятой на себя обязанности, любовное отношение к своему делу и искреннее стремление способствовать всеобщему благу!» 65 .

К сожалению, почти все сказанное можно отнести и к современной России. И катастрофа, действительно, накрыла нашу страну цунами репрессий и культурного одичания. Но сегодня к ситуации, так точно указанной Зеньковским, добавились новые проблемы, о которых мы говорили выше. Тем не менее, жизнь не останавливается и ее нужно возобновлять в правильном направлении. Что же можно сказать в заключении о воспитании, имея в виду детство?

Стоит обратить внимание, что в настоящее время очень много форм и видов воспитания и образования: воспитание, ориентированное на техническую культуру, на гуманитарную, художественную, религиозную, эзотерическую, с национальным уклоном, военным, спортивным и т.д. И думаю, эта тенденция сохранится и в будущем и, возможно даже расширится. Правда, она отчасти входит в противоречие с некоторыми задачами детства; например, как часто мы слышим, что вот мол ребенок начал очень рано заниматься музыкой или спортом и у него не было детства. Но думаю, сохранятся и указанные выше этапы и средства, характерные для детства. Все равно ребенок должен овладеть языком, научиться строить отношения с взрослыми и детьми, развиваться в направлении к отрочеству (т.е. быть готовым к преображению в личность), и вряд ли будут придуманы более эффективные средства, чем игра, сказка или схемы (хотя кто знает, но даже, если и будут изобретены, то, как показывает история, в культуре ничего не исчезает насовсем).

Иногда приходится слышать: «у меня было счастливое детство». Что это значит? Не то ли, что родители понимали ребенка, поддерживали его, любили, и одновременно правильно направляли, что и позволило ему стать полноценной личностью и нравственным человеком? Здесь, конечно, кто-то может возразить и сказать: все верно, кроме «нравственного человека»», да и что сегодня это значит - совершенно непонятно. Соглашусь, что непонятно, но не приму утверждение, что можно правильно воспитать ребенка, игнорируя нравственные и духовные ценности. Правда, как понимать последние, да и само нравственное воспитание, если вспомнить, что сущность отношений детства во многом связаны с прамы? Можно ли нравственно воспитывать своего ребенка, если для самих родителей эти ценности и категории пусты и ничего не значат? А сегодня, к сожалению, не так уж много людей живут, следуя нравственным ценностям и категориям.

Выход один: воспитывать нравственно и своего ребенка и себя, не считать, что мы всегда знаем, как вести себя правильно в современных сложных противоречивых ситуациях, продумывать их, искать решение. В настоящее время родитель или педагог должен примириться с мыслью, что он не знает, как правильно воспитывать и не знает, что означает само это «правильно». Его задача осмыслять и, что такое правильное воспитание и, правильно ли он сам воспитан. И не просто констатировать сложившуюся ситуацию, а работать над её разрешением, чтобы детство наших детей, действительно было счастливым.

Продолжение следует

\section{Список литературы:}

1. Абраменкова В.В. Социальная психология детства в контексте развития отношений ребенка в мире // Вопросы психологии. 2002.

2. Августин А. Антология средневековой мысли. Т. 1. СПб.: РХГИ, 2001.

3. Апулей. Метаморфозы в XI книгах. М., 1960.

4. Артемьева Е.Ю. Психология субъективной семантики. М., 1980

5. Арьес Ф. Ребенок и семейная жизнь при Старом порядке. Екатеринбург: Изд-во Урал, ун-та, 1999

65 Зеньковский В. Психология детства. С. 296, 300301, 303, 329, 331, 343 . 
6. Асмолов А. Г. Психология личности. Принципы общепсихологического анализа. М., 2001.

7. Ахутин А. В. Открытие сознания // Человек и культура. М., 1990.

8. Бердяев Н. Самопознание (опыт философской автобиографии). М. 1990.

9. Выготский Л.С. Мышление и речь. Собр. соч. Т.2, М.,1982.

10. Годфруа Ж. Что такое психология. В 2-х т. Т. 2. М., 1992.

11. Герман Гессе О старости. 1952 http://www.lib.ru/GESSE/starost.txt

12. Детство как предмет научного исследования. http://vkjournal.ru/doc/105031.

13. Дэвид-Ниль А. Мистики и маги Тибета. “Васанта”. 1992

14. Ермолаева М. В. Практическая психология старости. М., 2002.

15. Зеньковский В.В. Психология детства. Ред. Golden-Ship.ru 2012. (Текст публикуется по изданию: Зеньковский В.В., проф. Психология детства. Лейпциг: Изд-во «Сотрудник», 1924).

16. Кле М. Психология подростка // Фролов Ю.И. Психология подростка.М., 1997.

17. Кон И. С. Ребенок и общество. - М., 1988.

18. Кон И. С. Открытие «Я». - М., 1978.

19. Красильщиков А. Еврейская месть. Быль. ЕС. N 3. 24-30 января 2007.

20. Леон-Портилья М. Философия нагуа. М., 1961.

21. Мелетинский Е.М. Поэтика мифа. М., 1976.

22. Мид М. Культура и мир детства. - М., 1988.

23. Неретина С.С. Точки на зрении. Санкт-Петербург, 2005.

24. Платон. Апология Сократа // Платон. Соч: В 4 т. Т.1. М., 1994.

25. Платон Государство. Собр. соч. в 4 т. Т. 3. М., 1994.

26. Платон. Собр. соч. в 4 т. Т. 4. М., 1994.

27. Померанц Г.С. Постмодернизм // Новая философская энциклопедия. В 4 т. М, 2001. Т. 3.

28. Психология детства. Учебник. М., 2003.

29. Роджер Алан Дикон Производство субъективности // Логос. \# 2 (65) 2008.

30. Розин В.М. Культурология. Учебник. 2-е изд. М., 2004.

31. Розин В.М. Человек культурный. Введение в антропологию. М., 2003

32. Розин В.М. Философия образования. Этюды-исследования (параграф «Каким образом и от кого произошел человек?»). Москва-Воронеж, 2007.

33. Розин В.М. Теория культуры. М., 2004

34. Розин В.М. Визуальная культура и восприятие. Как человек видит и понимает мир. Изд. 5. M,. 2012.

35. Розин В.М. Философия техники. От египетских пирамид до виртуальных реальностей. М., 2001

36. Тейлор Э. Первобытная культура. М., 1939.

37. Хюбнер К. Истина мифа. М., 1996.

38. Чуковский К. От двух до пяти. http://www.litmir.net/br/?b=72192

39. Юнг К. Воспоминания, сновидения, размышления. Киев, 1994.

40. Meltzoff, A.N., \& Moore, M.K. (1977). «Imitation of Facial and Manual Gestures by Human Neonates.». Science, vol. 198, 1977.

41. http://rudocs.exdat.com/docs/index-370609.html

\section{References (transliteration):}

1. Abramenkova V.V. Sotsial'naya psikhologiya detstva v kontekste razvitiya otnoshenii rebenka v mire // Voprosy psikhologii. 2002.

2. $\quad$ Avgustin A. Antologiya srednevekovoi mysli. T. 1. SPb.: RKhGI, 2001.

3. Apulei. Metamorfozy v XI knigakh. M., 1960.

4. Artem'eva E.Yu. Psikhologiya sub"ektivnoi semantiki. M., 1980

5. Ar'es F. Rebenok i semeinaya zhizn' pri Starom poryadke. Ekaterinburg: Izd-vo Ural, un-ta, 1999

6. Asmolov A. G. Psikhologiya lichnosti. Printsipy obshchepsikhologicheskogo analiza. M., 2001.

7. $\quad$ Akhutin A. V. Otkrytie soznaniya // Chelovek i kul'tura. M., 1990.

8. Berdyaev N. Samopoznanie (opyt filosofskoi avtobiografii). M. 1990.

9. Vygotskii L.S. Myshlenie i rech'. Sobr. soch. T.2, M.,1982.

10. Godfrua Zh. Chto takoe psikhologiya. V 2-kh t. T. 2. M., 1992. 


\section{Культура и искусство 2(20) • 2014}

11. German Gesse O starosti. 1952 http://www.lib.ru/GESSE/starost.txt

12. Devid-Nil' A. Mistiki i magi Tibeta. "Vasanta". 1992

13. Ermolaeva M. V. Prakticheskaya psikhologiya starosti. M., 2002.

14. Zen'kovskii V.V. Psikhologiya detstva. Red. Golden-Ship.ru 2012. (Tekst publikuetsya po izdaniyu: Zen’kovskii V.V., prof. Psikhologiya detstva. Leiptsig: Izd-vo «Sotrudnik», 1924).

15. Kle M. Psikhologiya podrostka // Frolov Yu.I. Psikhologiya podrostka.M., 1997.

16. Kon I. S. Rebenok i obshchestvo. - M., 1988.

17. Kon I. S. Otkrytie "Ya". - M., 1978.

18. Krasil'shchikov A. Evreiskaya mest'. Byl'. ES. N 3. 24-30 yanvarya 2007.

19. Leon-Portilya M. Filosofiya nagua. M., 1961.

20. Meletinskii E.M. Poetika mifa. M., 1976.

21. Mid M. Kul'tura i mir detstva. - M., 1988.

22. Neretina S.S. Tochki na zrenii. Sankt-Peterburg, 2005.

23. Platon. Apologiya Sokrata // Platon. Soch: V 4 t. T.1. M., 1994.

24. $\quad$ Platon Gosudarstvo. Sobr. soch. v 4 t. T. 3. M., 1994.

25. Platon. Sobr. soch. v 4 t. T. 4. M., 1994.

26. Pomerants G.S. Postmodernizm // Novaya filosofskaya entsiklopediya. V 4 t. M, 2001. T. 3.

27. Rodzher Alan Dikon Proizvodstvo sub"ektivnosti // Logos. \# 2 (65) 2008.

28. Rozin V.M. Kul'turologiya. Uchebnik. 2-e izd. M., 2004.

29. Rozin V.M. Chelovek kul'turnyi. Vvedenie v antropologiyu. M., 2003

30. Rozin V.M. Filosofiya obrazovaniya. Etyudy-issledovaniya (paragraf «Kakim obrazom i ot kogo proizoshel chelovek?»). Moskva-Voronezh, 2007.

31. Rozin V.M. Teoriya kul'tury. M., 2004

32. Rozin V.M. Vizual'naya kul'tura i vospriyatie. Kak chelovek vidit i ponimaet mir. Izd. 5. M,. 2012.

33. Rozin V.M. Filosofiya tekhniki. Ot egipetskikh piramid do virtual'nykh real'nostei. M., 2001

34. Teilor E. Pervobytnaya kul'tura. M., 1939.

35. Khyubner K. Istina mifa. M., 1996.

36. Chukovskii K. Ot dvukh do pyati. http://www.litmir.net/br/?b=72192

37. Yung K. Vospominaniya, snovideniya, razmyshleniya. Kiev, 1994.

38. Meltzoff, A.N., \& Moore, M.K. (1977). «Imitation of Facial and Manual Gestures by Human Neonates.» Science, vol. 198, 1977. 